\title{
Biostimulant Properties of Seaweed Extracts in Plants: Implications towards Sustainable Crop Production
}

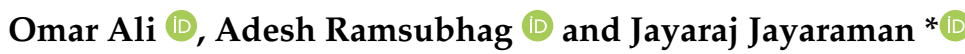 \\ Department of Life Sciences, Faculty of Science and Technology, The University of the West Indies, St. Augustine, \\ Trinidad and Tobago; omarali0418@gmail.com (O.A.); Adesh.Ramsubhag@gmail.com (A.R.) \\ * Correspondence: Jayaraj.Jayaraman@sta.uwi.edu; Tel.: +868-662-2002 (ext. 85244)
}

Citation: Ali, O.; Ramsubhag, A.; Jayaraman, J. Biostimulant Properties of Seaweed Extracts in Plants: Implications towards Sustainable Crop Production. Plants 2021, 10, 531 https://doi.org/10.3390/ plants10030531

Academic Editor: Filippo Maggi Received: 24 December 2020

Accepted: 23 January 2021

Published: 12 March 2021

Publisher's Note: MDPI stays neutral with regard to jurisdictional claims in published maps and institutional affiliations.

Copyright: (c) 2021 by the authors. Licensee MDPI, Basel, Switzerland. This article is an open access article distributed under the terms and conditions of the Creative Commons Attribution (CC BY) license (https:/ / creativecommons.org/licenses/by/ $4.0 /)$.

\begin{abstract}
The use of seaweed-based bioproducts has been gaining momentum in crop production systems owing to their unique bioactive components and effects. They have phytostimulatory properties that result in increased plant growth and yield parameters in several important crop plants. They have phytoelicitor activity as their components evoke defense responses in plants that contribute to resistance to several pests, diseases, and abiotic stresses including drought, salinity, and cold. This is often linked to the upregulation of important defense-related genes and pathways in the plant system, priming the plant defenses against future attacks. They also evoke phytohormonal responses due to their specific components and interaction with plant growth regulation. Treatment by seaweed extracts and products also causes significant changes in the microbiome components of soil and plant in support of sustainable plant growth. Seaweed extracts contain a plethora of substances which are mostly organic, but trace levels of inorganic nutrient elements are also present. Fractionation of seaweed extracts into their components and their respective bioassays, however, has not yielded favorable growth effects. Only the whole seaweed extracts have been consistently proven to be very effective, which highlights the role of multiple components and their complex interactive effects on plant growth processes. Since seaweed extracts are highly organic, they are ideally suited for organic farming and environmentally sensitive crop production. They are also very compatible with other crop inputs, paving the way for an integrated management approach geared towards sustainability. The current review discusses the growth and functional effects evoked by seaweed extracts and their modes and mechanisms of action in crop plants which are responsible for elicitor and phytostimulatory activities. The review further analyses the potential value of seaweed extracts in integrated crop management systems towards sustainable crop production.
\end{abstract}

Keywords: seaweed extracts; phytoelicitor components; phytostimulation; stress tolerance; mechanisms of action; organic inputs; sustainable agriculture

\section{Introduction}

Research efforts have been undertaken over decades to find various workable organic agricultural inputs that are not only beneficial to humans but also remain sustainable towards the environment. With the onset of climate change, pesticide resistance, and the continuous loss of land due to overgrowing populations, the need for new innovative agricultural practices is paramount more than ever.

The term biostimulants refers to substances of biological origin or microorganisms which, when applied to plants either via root drench, foliar spray, or a combination of both, is intended to stimulate natural processes in the plant that is responsible for efficient plant nutrient use efficiency and growth processes and/or an increase in the tolerance to abiotic and biotic stress, irrespective of the plant-beneficial nutrient content of the substances [1,2]. Algal extracts are biostimulants rather than fertilizers since they stimulate defense and growth response when applied to the plant. Furthermore, the profiles of algal extracts have not been shown to naturally contain fertilizer compounds at the level to 
qualify it as a fertilizer. Much focus has been placed on seaweed-based extracts recently since studies revealed that these complex mixtures possessed assorted biostimulatory compounds such as various forms of carbohydrates, amino acids, small quantities of phytohormones, osmoprotectants, and proteins [3,4]. In addition to enhancing stress tolerance, nutrient uptake, growth, and yield, seaweed-based biostimulants have also been shown to help reduce seed dormancy and enhance root systems, flowering [5], fruit quality, and taste [6], and even the quality of produce [7]. These all-round effects lead to improved crop productivity.

Seaweeds are macroalgae which constitute an integral component of marine and coastal ecosystem, contributing to their rich biodiversity and to the overall biosphere. There are three classes of seaweeds based on their color, which have been commercially utilized for various purposes including agriculture (Table 1). Some of the seaweeds are abundantly available and also commonly found irrespective of the geographical location, though some of them are specific to certain regions. During recent years, there has been a huge influx of Sargassum in many parts of the Americas and the Caribbean. Although massive quantities of the seaweed being deposited on the coasts frequently create environmental crises, there is also an opportunity for undertaking innovative actions for the valorisation of this biomass, rather than simply discarding in landfills or leaving it to decay. This could be very well realized by the production of seaweed-based biostimulants and other bioproducts. Interestingly, seaweed extracts have repeatedly been shown to contribute to plant growth promotion, increased yields, and plant's tolerance to abiotic and biotic stresses [8]. This is certainly a promising and sustainable approach that farmers can incorporate in to their farming systems, even in integrated crop management whereby efforts can be made to minimize chemical pesticide usage by replacing the synthetic inputs with seaweed extracts/products. Furthermore, efforts have been made to understand comprehensively how these seaweed extracts work at influencing such an increase in overall crop productivity via the global exploration of differential gene expression. The question of where these seaweed-based biostimulants stand is still pertinent to some. In this respect, the current review dives into the effects of seaweed extracts on economically important crops which will then be synchronized with the mechanism of action at the genetic and metabolic planes. The review will portray the usage of these extracts in complementation with marginal levels of chemical inputs to produce the most sustainable outcome in agriculture, both economically and environmentally.

Table 1. List of important seaweed species with documented biostimulatory activities.

\begin{tabular}{ccc}
\hline Phaeophyceae & Rhodophyta & Chlorophyta \\
\hline Ascophyllum nodosum & Macrocycstis pyrifera & Ulva lactuca \\
\hline Ecklonia maxima & Porphyra perforate & Enteromorpha prolifera \\
\hline Durvillea antarctica & Nereocystis spp. & Caulerpa paspaloides \\
\hline Durvillea protatorum & Cyanidium caldarium & Ulva armoricana \\
\hline Fucus vesiculosus & Gelidium serrulatum & Codium Liyengarii \\
\hline Sargassum spp. & Acanthophora spicifera & Codium tomentosum \\
\hline Hydroclathrus spp. & Kappaphycus alvarezii & Caulerpa sertularioides \\
\hline Ralfsia spp. & Gracilaria edulis & \\
\hline Laminaria digitata & Gracilaria dura & \\
\hline Cystoseira myriophylloides & Laurencia johnstonii & \\
\hline Fucus spiralis & & \\
\hline Padina pavonica & & \\
\hline Fucus gardneri & & \\
\hline Durvillaea antarctica & & \\
\hline
\end{tabular}




\section{Seaweed Extracts-Methods of Preparation and Application into Plants}

Both physical methods (heat, pressure, and microwaves) and chemical methods (solvents, acids, and alkali) are used for the extraction of seaweeds. The choice of extraction method should be able to deal with the complexity of the seaweed composition and guarantee the integrity of biologically active molecules that have biostimulant value. The most widely used extraction process involves alkaline extraction at high pressure. This method has been found to be optimally effective, although some hormonal molecules can be degraded. The advantage of this method is the high level of extractability and moderate degradation of polysaccharides into oligomers which are one of the most biologically active components of seaweed extracts $[9,10]$.

The method of application of the seaweed extracts plays an important role in their use and responses by plants. Most application types are either foliar, root application, or a combination of both. The extracts can be applied to soil or growing medium through fertigation, drenching or dripping [11]. However, foliar sprays of less than or equal to $0.05 \%$ $\mathrm{v} / \mathrm{v}$ of the extract have been reported to be optimal for the crop and result in more effective control of disease and higher yields [12]. The better performance of foliar applications has been attributed to the immediate interaction with the plant tissues because foliar absorption happens almost immediately. Further, the adsorption of extracts by soil particles is common, which may reduce its instant mobility $[12,13]$. Additionally, the optimal application times for these extracts were determined to be around every 10-14 days for provoking the best plant responses [14].

\section{Effect of Seaweed Extracts on Plant Growth}

Over the decades, seaweed extracts have been highly explored for possible use in crop production for improving biomass yield and produce quality. These extracts have been shown to positively affect seed germination and plant growth at all stages up to harvest and even post-harvest $[5,13]$ (Table 2). Seaweed products have been shown to promote increased germination rates and cause significant increases in seedling vigor by enhancing root size and density [15]. The extracts have also been shown to protect seedlings from transplantation shock in tomato, cabbage, and marigold $[16,17]$. The improved rooting architecture could be a result of small levels of phytohormones present in the extracts such as auxins as well as various stimulatory processes engaged in the plant system upon treatment with these extracts [18]. The enhancement of root systems of plants treated with seaweed extracts was also observed in vegetatively propagated plants. For instance, cuttings from floricultural plants such as marigold treated with an extract from E. maxima led to an increase in root density [19]. This was also reported in stone pine cuttings treated with E. maxima extract which is otherwise very difficult to root [20]. Treatment with $A$. nodosum extract was able to increase the number of propagules per plant in daylilies [21]. Extracts of A. nodosum and K. alvarezii also improved water uptake and nutrients, which ultimately led to the promotion of overall vigor and the growth of plants [22,23]. Application of $A$. nodosum and Laminaria spp. extracts in maize showed that leaves were able to significantly absorb more $\mathrm{Zn}, \mathrm{Fe}, \mathrm{B}, \mathrm{Cu}, \mathrm{Mo}, \mathrm{S}, \mathrm{Mg}, \mathrm{Ca}$, and $\mathrm{Mn}$ than the controls [24]. Applications of $A$. nodosum on cottonwood significantly increased potassium uptake in the leaves [25]. A similar increase in potassium levels was also observed in the leaves of mustard treated with E. maxima [26].

Seaweed extracts are also reported to have or influence phytohormonal activity. Results of a study in spinach treated with E. maxima extracts showed the increase of plants endogenous cytokinins, isopentyladenine, dihydrozeatin, and cis-zeatin which have all been linked to positive plant growth [27]. At the plant's vegetative stage, application of A. nodosum in tomato and sweet pepper led to the increased chlorophyll content of leaves which was probably due to inhibition of chlorophyll degradation caused partly by betaines present in the extract $[28,29]$. These betaine compounds in the seaweed extracts suspend photosynthetic activity loss by the inhibition of chlorophyll degradation [30]. Similarly, a significant increase in chlorophyll content, stomatal conductance, photosynthetic rate, 
and transpiration rates were recorded in asparagus plants treated with A. nodosum [31]. Treatment of willow plants with an extract of E. maxima enhanced the electron transfer rates of both photosystems [32]. Tomato plants treated with red, brown, and green species of seaweed extracts resulted in increased plant height, increased leaf numbers, increased root width and root length, and an overall increase in biomass $[5,33]$.

Seaweed extracts also triggered early flowering and increased fruit set in a variety of crop plants, for example, tomato, pepper, and snap bean $[5,12,34,35]$. These increases in flower numbers and fruit set inevitably led to an improvement in yields. For instance, the application of seaweed extracts in tomatoes caused a significant increase in flower number, inflorescence number, flower to fruit ratio, and increased fruit number and size [26,28]. This yield increase was thought to be as a result of various levels of phytohormones present in the extracts such as cytokinins and induction of host hormonal synthesis [36]. Recent studies have shown that seaweed extracts and their components can modulate the expression of genes responsible for the endogenous biosynthesis of growth hormones including auxin, cytokinin, and gibberellin [5]. This was reported in tomato and sweet pepper plants treated with extracts of $A$. nodosum, S. vulgare, and A. spicifera $[5,13]$. Apart from increasing harvestable crop yield, extracts have been reported to enhance the nutrient quality of crops such as tomato, pepper, lettuce, spinach, cucumber, and strawberry [6,12,37-39]. Treatment of cucumber with an extract of Macrocystis pyrifera led to significant increases in total phenols, antioxidant capacity, and vitamin C in the fruits [39]. Applications of $A$. nodosum lead to increases in anthocyanins and total phenolic contents in the grapevines and berries [40]. Strawberry plants treated with $A$. nodosum seaweed extract improved the edible quality of the fruit by enhancing total soluble solids, sucrose, and fructose. The same study also reported an increase in a health compound, quercetin, which has been highly documented as a cardiovascular promoter and anticancer-reducing agent [6]. Application of an extract of Codium tomentosum as a postharvest spray to apples resulted in a reduced browning index coupled with inhibition of peroxidase and polyphenol oxidase, enzymes linked to browning which can reduce the shelf life of the produce [41]. These booster effects have been shown to accumulate in the plant irrespective of the type of application done, i.e., foliar, soil root drench, or a combination of both [12,42,43]. Ashing of the seaweed extract product leads to the loss of biostimulant activity which confirmed the role of organic fraction of these seaweed extracts in eliciting positive growth responses in plants [42]. Though seaweed extract biostimulants contain minimum levels of minerals that plants can readily assimilate, the main contribution of the extracts is their ability to stimulate various processes in the plant system which would eventually allow for enhanced growth and productivity of plants $[5,44,45]$.

\section{Effect of Seaweed Extracts on Plants' Tolerance to Biotic Stresses}

The ever-changing climate and the extensive overuse of chemical pesticides have increased the emergence of infectious and resistant pests and pathogens in major crops, thus substantially reducing agricultural outputs [46,47]. Nematode parasites cause serious infestation and damage to plants; however, seaweed extracts have been shown to reduce the infestation of nematodes in plants such as Arabidopsis thaliana [43], sunflower [44], and tomato [45]. However, this nematocidal activity is largely a part of the plant's defense response, possibly by cytokinin: auxin ratio adjustments as it was shown that seaweed extracts had no direct nematicidal properties [48]. Furthermore, extracts of Sargassum wightii and Padina pavonica showed significant insecticidal activity against the red cotton stainer (Dysdercus cingulatus) which is a serious pest harming cotton crops [49]. The infestation of greenfly aphid (Aphis gossypii) and serpentine leafminer (Liriomyza trifolii) was also significantly reduced in cotton upon mixed treatments with Sargassum spp., A. nodosum, Laminaria spp. [50]. On the other hand, citrus greening was also reduced by a reduction of the pest Diaphorina citri upon treatment with extracts of Caulerpa sertularioides, Laurencia johnstonii and Sargassum horridum [51]. Additionally, seaweed extracts were able to significantly reduce infestation caused by borers, aphids, and thrips in sugarcane thus 
preventing great economic loss $[52,53]$. This reduction in infestation can be due to the antifeedant effects, growth inhibition, and also cytotoxicity on ovarian tissue cells of the pests. For example, an acyclic diterpenoid isolated from Sargassum had growth repellent effects against pink bollworm [54].

Seaweed extracts also serve as elicitors to plant defense responses against harmful bacterial, fungal, and even viral pathogens thereby protecting crops from major economic damage from diseases [4,25]. Extracts of various brown, red, and green macroalgae (Table 2) were recorded to have great eliciting effects against some harmful bacterial and fungal pathogens. There were several fungal and bacterial diseases that were controlled by the application of seaweed extracts. The reduction of infection levels is due to a general improvement of vigor of seaweed extract treated plants, preformed resistance, induced systemic or systemic acquired resistance, or enhanced soil suppressiveness due to altered microbial dynamics.

Apart from eliciting defense towards bacterial and fungal pathogens, seaweed extracts have shown the potential to control the harsh symptoms of viroid and viruses of plants [55]. Symptoms of the tomato chlorotic dwarf viroid were significantly decreased when pretreated with a $\lambda$-carrageenan polysaccharide from a seaweed extract. Similarly, the severity of tobacco mosaic virus (TMV) in tobacco was significantly reduced when treated with sulfated galactans which are a major component of some of the seaweed extracts [55]. Furthermore, treatment of plants with oligosaccharides derived from seaweeds showed a significant reduction of symptoms caused by tobacco mosaic virus in tobacco plants [56,57].

\section{Effect of Seaweed Extracts on Plants' Tolerance to Abiotic and Environmental Stresses}

In addition to stresses caused by pests and diseases, various environmental stresses such as drought, high temperature, salt, and freezing conditions can hamper crop productivity. It is also estimated that by the year 2050, approximately $50 \%$ of arable lands will be plagued by high salt and drought conditions. These abiotic stresses can lead to the build-up of reactive oxygen species (ROS) which will ultimately cause damage to the plant system [56,57]. Interestingly, plants treated with seaweed extracts such as A. nodosum and Sargassum spp. were able to withstand the damaging effects of these abiotic stresses (Table 2). For example, a significant reduction was recorded in leaf osmotic potential when grapevines and tomato plants were treated with seaweed extracts thus preventing extensive damage [58]. Kappaphycus alvarezzi extract treatment on various wheat varieties under salinity and drought stress resulted in plants with increased root length, enhanced chlorophyll content and carotenoids, and tissue water content. The extract also caused a significant reduction in electrolyte leakage and lipid peroxidation, decreased $\mathrm{Na}^{+} / \mathrm{K}^{+}$ ratio, and increased $\mathrm{Ca}$ content, thereby reducing ionic disparity. Further, treated wheat plants accumulated osmoprotectants including proline, amino acids, and total protein [59]. Seaweed extracts also promote freezing tolerance in barley [60] and $A$. thaliana [61] with an increase in winter hardiness when treated with seaweed extract sprays. Seaweed extractinduced attenuation of the harsh effects of drought, cold, and salinity stress has shown to be mediated through enhanced root morphology, a build-up of non-structural carbohydrates which improved storage of energy, enhanced metabolism, and water adjustments, as well as the build-up of proline $[60,61]$.

The enhancement and priming effects of seaweed extracts on the plant's defenses against both abiotic and biotic stresses can be attributed to the chemical composition of the extracts as well as its eliciting properties [1]. In the subsequent sub-sections, we will reveal the proposed modes of action of seaweed extracts in eliciting growth and defense responses as well as discuss their compositional features in relation to the varying responses recorded [9]. 
Table 2. Effect of seaweed extract biostimulants on major crops.

\begin{tabular}{|c|c|c|c|}
\hline Crop & Seaweed Extract & Observed Effects & Reference \\
\hline $\begin{array}{l}\text { Tomato } \\
\text { (Solanum lycopersicum) }\end{array}$ & $\begin{array}{ll}\text { - } & \text { Ascophyllum nodosum } \\
\text { - } & \text { Sargassum spp. } \\
\text { - } & \text { Cystoseira } \\
& \text { myriophylloides } \\
\text { - } & \text { Gelidium serrulatum } \\
\text { - } & \text { Ulva lactuca } \\
\text { - } & \text { Laminaria digitata } \\
\text { - } & \text { Fucus spiralis } \\
\text { - } & \text { A. spicifera }\end{array}$ & $\begin{array}{ll}\text { - } & \text { Increased germination rate and } \\
\text { - } & \text { seedling vigor } \\
\text { - } & \text { Increased shoot and root growth } \\
\text { Increased chlorophyll content (Soil Plant } \\
\text { - } \quad \text { Analysis Development-SPAD index) } \\
\text { - } \quad \text { Increased flowering } \\
\text { - } & \text { Fruit yield increase } \\
- & \text { Fruit quality improvement } \\
\text { Improved resistance to pathogens: } \\
\text { Verticillium wilt (Verticillium dahliae), early } \\
\text { blight (Alternaria solani), crown gall } \\
\text { (Agrobacterium tumefaciens), and bacterial } \\
\text { spot (Xanthomonas campestris pv. vesicatoria) } \\
\text { Increased tolerance to salinity, drought, and } \\
\text { cold stress }\end{array}$ & {$[3,11,31,32,62-67]$} \\
\hline $\begin{array}{l}\text { Sweet pepper } \\
\text { (Capsicum annuum) }\end{array}$ & $\begin{array}{ll}\text { - } & \text { A. nodosum } \\
\text { - } & \text { Sargassum spp. } \\
\text { - } & \text { A. spicifera }\end{array}$ & $\begin{array}{ll}- & \text { Increased shoot and root growth } \\
- & \text { Increased chlorophyll content (SPAD index) } \\
- & \text { Increased flowering } \\
- & \text { Fruit yield increase } \\
- & \text { Fruit quality improvement } \\
- & \text { Improved resistance to pathogens: early } \\
\text { blight (Alternaria solani), blight and fruit rot } \\
\text { (Phytophthora capsica) and bacterial spot } \\
\text { (Xanthomonas campestris pv. vesicatoria) } \\
\text { - Increased tolerance to salinity and } \\
\text { drought stress }\end{array}$ & {$[3,11,60,61,63,68]$} \\
\hline Lettuce (Lactuca sativa) & $\begin{array}{ll}\text { - } & \text { A. nodosum } \\
\text { - } & \text { Durvillaea potatorum } \\
\text { - } & \text { Durvillaea antarctica } \\
\text { - } & \text { Ecklonia maxima }\end{array}$ & $\begin{array}{ll}- & \text { Increased root and shoot } \\
- & \text { Increased chlorophyll content } \\
- & \text { Increased photochemical efficiency and } \\
\text { increased activity of photosystem II } \\
\text { - } \quad \text { Marketable yield increase }\end{array}$ & {$[37,68]$} \\
\hline $\begin{array}{l}\text { Cauliflower (Brassica } \\
\text { oleracea) }\end{array}$ & A. nodosum & $\begin{array}{ll}\text { - } & \text { Increased heart size } \\
\text { - } & \text { Increased curd diameter }\end{array}$ & [69] \\
\hline Soybean (Glycine max) & $\begin{array}{ll}\text { - } & \text { A. nodosum } \\
\text { - } & \text { Kappaphycus alvarezii }\end{array}$ & $\begin{array}{ll}\text { - } & \text { Improved nutrient uptake } \\
\text { - } & \text { Enhanced yield parameters } \\
\text { - } & \text { Improved drought tolerance }\end{array}$ & {$[70-72]$} \\
\hline $\begin{array}{l}\text { Strawberry (Fragaria } x \\
\text { ananassa) }\end{array}$ & $\begin{array}{ll}\text { - } & \text { A. nodosum } \\
\text { - } & \text { Sargassum sp. } \\
\text { - } & \text { Laminaria sp. } \\
\text { - } & \text { Duvillaea potatorum }\end{array}$ & $\begin{array}{ll}- & \text { Increased vegetative growth } \\
- & \text { Increased crown carbohydrate, leaf } \\
\text { phosphorus, and potassium contents } \\
\text { - } & \text { Increased yield } \\
- & \text { Enhanced fruit quality and taste } \\
\text { - } & \text { Increased resistance to powdery mildew } \\
\text { (Podosphaera aphanis), grey mold (Botrytis } \\
\text { cinerea), leak (Rhizopus and Mucor spp.), } \\
\text { anthracnose (Colletotrichum acutatum), leather } \\
\text { rot (Phytophthora cactorum), and stem end rot } \\
\text { (Gnomonia comari) }\end{array}$ & {$[6,72-75]$} \\
\hline $\begin{array}{l}\text { Cucumber (Cucumis } \\
\text { sativus) }\end{array}$ & $\begin{array}{ll}- & \text { A. nodosum } \\
- & \text { Macrocystis pyrifera } \\
\text { - } & \text { Ulva armoricana }\end{array}$ & $\begin{array}{ll}- & \text { Increased fruit yield } \\
- & \text { Enhanced nutritional fruit content } \\
- & \text { Reduced fungal infections by leafspot } \\
\text { (Alternaria cucumerinum), blight (Didymella } \\
\text { applanata), wilt (Fusarium oxysporum), grey } \\
\text { mold (Botrytis cinerea), and powdery mildew } \\
\text { (Erysiphe polygoni, E. necator and Sphareotheca } \\
\text { fuliginea) }\end{array}$ & {$[76-78]$} \\
\hline
\end{tabular}


Table 2. Cont.

\begin{tabular}{|c|c|c|c|}
\hline Crop & Seaweed Extract & Observed Effects & Reference \\
\hline Onion (Allium сера) & A. nodosum & $\begin{array}{ll}- & \text { Increased germination rate and seedling } \\
\text { - } & \text { vigor } \\
- & \text { Increased bulb diameter and weight } \\
- & \text { Increased mineral content } \\
- & \text { Increased ascorbic acid } \\
\text { - } & \text { Disease reduction caused by downy mildew } \\
\text { (Peronospora destructor) } \\
\text { - } & \text { Aided in water stress resistance and } \\
& \text { increased N, P, K uptake }\end{array}$ & [79-82] \\
\hline $\begin{array}{l}\text { Potato (Solanum } \\
\text { tuberosum) }\end{array}$ & $\begin{array}{ll}\text { - } & \text { A. nodosum } \\
\text { - } & \text { K. alvarezii } \\
\text { - } & \text { Gracilaria edulis } \\
\text { - } & \text { E. maxima }\end{array}$ & $\begin{array}{ll}\text { - } & \text { Growth improvement } \\
\text { - } & \text { Increased yield and tuber quality } \\
\text { - } & \text { Increased resistance to drought stress }\end{array}$ & [83-87] \\
\hline $\begin{array}{l}\text { Broccoli (Brassica } \\
\text { oleracea var. italica) }\end{array}$ & - $\quad$ A. nodosum & $\begin{array}{ll}- & \text { Increased biomass } \\
- & \text { Increased nutritional value }\end{array}$ & {$[87,88]$} \\
\hline $\begin{array}{l}\text { Spinach } \\
\text { (S. oleracea) }\end{array}$ & $\begin{array}{ll}\text { - } & \text { A. nodosum } \\
\text { - } & \text { E. maxima } \\
\text { - } & \text { Codium liyengarii }\end{array}$ & $\begin{array}{ll}- & \text { Increased fresh yield, dry biomass and leaf } \\
\text { area } & \\
\text { - } & \text { Increased SPAD index } \\
\text { - } & \text { Increased micro/macronutrient profile } \\
\text { - } & \text { Increased resistance to drought stress }\end{array}$ & {$[34,89-91]$} \\
\hline Carrot (Daucus carota) & $\begin{array}{ll}\text { - } & \text { A. nodosum } \\
\text { - } & \text { E. maxima }\end{array}$ & $\begin{array}{ll}- & \text { Increased harvest index }(\mathrm{HI}) \\
- & \text { Improved nutritional content } \\
- & \text { Reduction of fungal disease severity caused } \\
\text { by black rot (Alternaria radicina) and grey } \\
\text { mold (B. cinerea) }\end{array}$ & [92-96] \\
\hline $\begin{array}{l}\text { Wheat (Triticum } \\
\text { aestivum) }\end{array}$ & $\begin{array}{ll}\text { - } & \text { A. nodosum } \\
\text { - } & \text { E. maxima } \\
\text { - } & \text { K. alvarezii } \\
\text { - } & \text { G. edulis } \\
\text { - } & \text { G. dura } \\
\text { - } & \text { Sargassum latifolium } \\
\text { - } & \text { Ulva lactuca }\end{array}$ & $\begin{array}{ll}\text { - } & \text { Increased chlorophyll content (>SPAD) } \\
\text { - } & \text { Increased yield } \\
\text { - } & \text { increased micro/macronutrients in root, } \\
\text { leaves, and grains } \\
\text { - } \quad \text { Increased protein content } \\
\text { - } & \text { Improved drought and salinity tolerance }\end{array}$ & {$[43,97-102]$} \\
\hline Rice (Oryza sativa) & $\begin{array}{ll}\text { - } & \text { A. nodosum } \\
\text { - } & \text { Kappaphycus sp. } \\
\text { - } & \text { Gracilaria sp. } \\
\text { - } & \text { Hydroclathrus sp. } \\
\text { - } & \text { Sargassum sp. }\end{array}$ & $\begin{array}{ll}\text { - } & \text { Greater germination \% and seedling vigor } \\
\text { - } & \text { Improved yield } \\
\text { - } & \text { Improved nutrient uptake }\end{array}$ & [103-106] \\
\hline $\begin{array}{l}\text { Apple (Malus } \\
\text { domestica) }\end{array}$ & $\begin{array}{ll}\text { - } & \text { A. nodosum } \\
\text { - } & \text { Codium tomentosum }\end{array}$ & $\begin{array}{ll}- & \text { Decreased alternate bearing } \\
\text { - } & \text { Greater chlorophyll content } \\
\text { - } & \text { Increased photosynthesis and respiration } \\
\text { - } & \text { rates } \\
\text { - } & \text { Increased fruit set and fruit yield } \\
\text { - } & \text { Increased anthocyanin content } \\
\text { - } & \text { Minimized fruit browning post-harvest }\end{array}$ & {$[39,107-110]$} \\
\hline
\end{tabular}


Table 2. Cont.

\begin{tabular}{|c|c|c|c|}
\hline Crop & Seaweed Extract & Observed Effects & Reference \\
\hline Maize (Zea mays) & $\begin{array}{ll}\text { - } & \text { A. nodosum } \\
\text { - } & \text { Laminaria sp. } \\
\text { - } & \text { Gracilaria edulis } \\
\text { - } & \text { K. alvarezii }\end{array}$ & $\begin{array}{ll}- & \text { Increased germination \% and rate } \\
- & \text { Increased seedling vigor } \\
- & \text { Increased shoot and root growth } \\
\text { - } & \text { Increased net carbon assimilation } \\
\text { - } & \text { Total grain yield }\end{array}$ & {$[22,111-115]$} \\
\hline Orange (Citrus spp.) & $\begin{array}{ll}\text { - } & \text { A. nodosum } \\
- & \text { E. maxima } \\
- & \text { Sargassum horridum } \\
- & \text { Laurencia johnstonii } \\
\text { - } & \text { Caulerpa sertularioides }\end{array}$ & $\begin{array}{ll}- & \text { Increase in maturity index (MI) } \\
- & \text { Lessened fruit drop } \\
- & \text { Increased yield } \\
- & \text { More vitamin C } \\
- & \text { Increased TSS } \\
- & \text { Significant control of the Asian citrus psyllid, } \\
& \text { Diaphorina citri }\end{array}$ & {$[14,49,116-118]$} \\
\hline $\begin{array}{l}\text { Sugarcane (Saccharum } \\
\text { officinarum) }\end{array}$ & A. nodosum & $\begin{array}{ll}- & \text { Increased biomass in plantlets } \\
- & \text { Increased plant growth parameters (SPAD, } \\
\text { - } & \text { height and leaf area index) } \\
- & \text { Increased yield } \\
- & \text { Improved sugar content } \\
\text { Enhanced water retention capacity and water } & \text { content } \\
- & \text { Lowered risk of wilting } \\
- & \text { Significant control of borers, aphids, and } \\
\text { thrips }\end{array}$ & {$[53,118,119]$} \\
\hline
\end{tabular}

\section{Mechanisms and Mode of Biostimulatory Activities}

Seaweed extracts have many growth benefits when applied to plants. However, these benefits are mostly due to their stimulatory feature which causes a cascade of reactions within the plant, thereby leading to overall growth and improvement to resist both biotic and abiotic stress (Figure 1). This section looks at the mode of biostimulatory action of seaweed extracts. However, it should be carefully noted that because seaweed extracts contain a myriad of bioactive ingredients, no one particular component can be allotted to the positive benefits observed (Figure 2; Table 3). In fact, trials using fractions of seaweed extracts have reported that no single fraction was able to replicate all the effects seen when the whole original extract is used. This trend, therefore, proves that the components of the whole extract work in synergy to evoke an overall positive response in the plant system where each component might act on various metabolic networks either independently or interactively $[107,120]$ (Figures 1 and 3).

Plants treated with seaweed extracts have shown generally improved nutrient acquisition capabilities and improved growth and vigor. A. nodosum extract-treated rapeseed plants showed an increase in nitrogen and sulfur acquisition. Transcription studies showed that this was due to an overexpression of the BnNRT1.1/BnNRT2.1 and BnSultr4.1/BnSultr4.2 genes which encode root transporters associated with the uptake of nitrogen, iron and sulfur [121]. This was explained as a result of the upregulation of genes coding sulphate, iron and nitrate transporters. Plant nutrient acquisition increased in seaweed extract treated plants was also evidenced by an increase in the transcription or activity of nutrient transporters in the plant membrane [122]. A study conducted in spinach using $A$. nodosum showed increased biomass, protein content, chlorophyll and carotenoid content, flavonoids and phenolics, and increased antioxidant activity. The increase in biomass was correlated with an increase in the expression of the GS1 gene involved in nitrogen integration. The increase in chlorophyll content was related to an increase in the expression of betaine aldehyde dehydrogenase and choline monooxygenase. The increase in chitinase activity, phenolics, and flavonoids was attributed to an increase in the expression of glutathione reductase, thylakoid bound ascorbate peroxidase APX, 
and monodehydroascorbate reductase. These genes were linked to the phenylpropanoid and flavonoid pathways which are known to stimulate growth and enhance overall nutrition [123]. A microarray study conducted on rapeseed showed the differential expression of 724 and 612 genes after 3 and 30 days of treatment, respectively. Ontologies of these genes showed involvement in carbon, sulfur, and nitrogen metabolism, cell metabolism, photosynthesis, and various metabolic pathways involved in phytohormone synthesis, fatty acids, plant development, and the transport of ions. Correlation analyses showed a link between differentially expressed genes and increased S, N, and sulfate as well as enhanced chlorophyll content and numbers of chloroplasts and starch granules, all of which led to improved growth. This led to the further hypothesis of an enhancement in carbon assimilation and the synthesis of starch which are linked to the enhanced expression of Rubisco and carbonic anhydrase [124]. A study conducted on tomato and bell pepper also demonstrated the effects of different seaweed extracts on major hormonal biosynthesis genes. Studies further revealed that seaweed extracts were able to significantly upregulate genes involved in auxin $(I A A)$, gibberellin $\left(G a_{2} \mathrm{O}_{x}\right)$, and cytokinin (IPT) biosynthesis which could be correlated to the increased plant growth effects $[5,13]$.

Seaweed extracts also aid plants to withstand harsh environmental conditions such as cold, drought, and salinity. Application of A. nodosum extracts protected Arabidopsis plants from induced cold stress by augmented chlorophyll content, possibly due to downregulation of chlorophyll degradation genes (AtCLH1 and AtCLH2). In addition, upregulation was observed with the transcription factor DREB1A and the COR78/RD29A genes encoding cryoprotection of chloroplast stromal protein, which are key regulators for cold stress tolerance [125]. The increase in proline, soluble sugar, and unsaturated fatty acid content was also related to increased tolerability to cold stress. Proline accumulation was supported by upregulation of 5CS1 and P5CS2 which are responsible for proline biosynthesis and the downregulation of $\mathrm{ProDH}$, a gene involved with proline degradation. The increase in soluble sugars was linked to the upregulation of polysaccharide degradation genes 9SEX1 and SEX4, upregulation of carbohydrate biosynthesis genes (GOLS2 and GOLS3), and the downregulation of sucrose degradation genes. In addition, the same study also reported the upregulation of the gene DGD1 which is involved in the synthesis of galactolipid that is known to play a role in cold stress tolerance. A study using tobacco cultures treated with A. nodosum extracts revealed the same trend wherein the treated cultures showed significant levels of tolerance to freezing stress. This trait was attributed to the upregulation of key freezing tolerance genes such as galactinol synthase 2, pyrroline 5-carboxylate synthase, and acetyl-CoA carboxylase [126].

Interestingly, seaweed extracts have been able to mitigate significantly the drought stress in plants, though its mechanism of action is still hazy at the most. Studies showed that seaweed extract treated plants under drought conditions have maintained higher relative water content, improved water use efficiency, stomatal conductance, and transpiration rate reduction. The increased expression of abscisic acid-responsive genes (At5g66400 and At5g52310) was noted in seaweed extract treated plants. The findings also revealed the optimal conservation of photosystem II (PSII) photochemistry and a boosted nonphotochemical quenching. Increased expression of the antioxidant coding genes At5g42800 and At1g8830 was also reported, which led to oxidative damage prevention to photosystem II in treated plants [127]. Reduced wilting and an increase in recovery rate, greater stomatal conductance, and augmented reactive oxygen scavenging activity were observed in soybean plants under drought stress when treated with seaweed extracts. Genes involved in ABA catabolism (GmCYP707A1a and GmCYP707A3b) were implicated in these results. The ABA-inducible GmDREB1B as well as the BURP domain protein-encoding GmRD22 were also significantly upregulated in seaweed extract treated plants. Interestingly, genes involved in the detoxification of ROS were also significantly upregulated (GmGST, GmBIP, and GmTP55) [70]. Similar drought stress mediation was also recorded in tomato in response to seaweed extract treatment. The lipid peroxidation levels were much lower compared to untreated plants under water stress. Furthermore, quantities of glucose, 
proline, and sucrose were significantly greater in treated tomato plants. Up to an 8-fold increase in the tas14 gene was seen in treated plants which encode for dehydrin proteins responsible for abiotic stress alleviation [128].

Apart from cold and drought stress, salinity stress also poses great threats to the agriculture sector and luckily, seaweed extracts can also alleviate this problem. A microarray analysis done on Arabidopsis plants presented the upregulation of 257 genes under saltinduced stress when treated with extracts. Highly upregulated genes included the late embryogenesis abundant 3 family and transcription factor Circadian Clock Associated 1 which have been linked to abiotic stress tolerance [120]. Other key genes induced were glutathione S-transferase-encoding, dehydration-responsive protein transcripts, ABA signaling genes (At5g62490 and At4g15910), and late embryogenesis abundant 1 and 2, which are all key players in the fight against abiotic stress [129]. The role of micro RNAs (miRNAs) has also been shown to impart drought stress alleviation as well as other abiotic stresses [70]. Over 106 miRNAs were significantly expressed in Arabidopsis under salinity stress when treated with seaweed extracts, some of which aid in both salinity as well as drought tolerance. Treated plants also showed lower sodium and higher phosphorous levels under $\mathrm{NaCl}$-induced stress conditions. Additionally, the genes involved in phosphate starvation regulation (ath-miR399a, ath-miR399b, ath-miR399c-3p, and ath-miR399c-5p) were significantly reduced with seaweed extract treatment [130]. An in vitro study conducted in tomato and sweet pepper showed that under $\mathrm{NaCl}$-induced stress, seedlings were able to overcome excessive oxidative damage when pre-treated with seaweed extract. This was correlated with the significant increase in the activity of antioxidant enzymes including ascorbate peroxidase and catalase [62]. A similar study conducted in biscuit grass under saline conditions showed the enhancement of lipid peroxidation and an increase in the activities of catalase, superoxide dismutase, and ascorbate peroxidase which ultimately led to a reduction of hydrogen peroxide levels in treated plants [131].

Apart from abiotic stresses, seaweed extracts have been able to enlist a number of defense mechanisms in plants against biotic stressors. The major cell wall polysaccharides of seaweeds such as ulvans, laminarins, and carrageenans and their derived oligosaccharides have been shown to confer some of these resistant responses in plants [55]. These bioactive molecules are known to induce an oxidative burst and various defense pathways mediated through salicylic acid, jasmonic acid, and ethylene. This cascade of reactions then leads to the accumulation of pathogenesis-related proteins (PR proteins), various defense enzymes such as chitinases and glucanases, and an increase in phenolic compounds which led to greater protection against a broad spectrum of pathogens. An extract from Ulva spp. applied to barrel clover under Colletotrichum trifolii infection led to an increase in the activity of defense enzymes such as phenylalanine ammonia-lyase, chitinase, chalcone synthase, and isoflavone reductase. This increase in defense enzymes led to the downregulation of genes responsible for carbon and nitrogen metabolism. This systematic response is quite normal as the plants use more resources to deploy the required pathways to protect itself under pathogenic attack. Interestingly, in vitro assays showed no direct inhibition of C. trifolli by seaweed extract application, suggesting that the defense mechanism is solely plant-based, through elicitation of key defense systems [132]. Similar studies conducted using Ascophyllum nodosum, Sargassum vulgare, and Acanthophora spicifera extracts also proved the absence of antimicrobial activity at the recommended concentrations [4,31]. A study conducted in tomato and sweet pepper recorded reduced infection levels by Xanthomonas campestris pv. vesicatoria and Alternaria solani, both in greenhouse and field conditions, following spray treatment by A. nodosum, Sargassum vulgare, and Acanthophora spicifera extracts. The extracts were able to significantly upregulate genes involved in SA and/or JA and ET mediated defense signaling including PR1-a, PinII, and ETR-1, respectively, as well as an increase in defense enzyme activity (phenylalanine ammonia-lyase, peroxidase, polyphenol oxidase, chitinase, and $\beta$-1,3-glucanase) $[5,13]$. Furthermore, the above studies also demonstrated no direct antimicrobial effects of the seaweed extracts, echoing the findings of Cluzet et al. [132]. The studies by Ramkissoon et al. [25] and Ali et al. [31] 
revealed an interesting observation about the elicitation of defense pathways by the types of seaweed extracts. In these studies, it was demonstrated that the treatment by extracts from the brown seaweeds (ex. Sargassum and Ascophyllum) had no significant effect on the SA pathway which was evidenced by no significant upregulation of $P R-1$ a transcripts in treated plants. However, brown seaweed extracts caused significant upregulation of both PinII and Etr-1 based defense pathways (JA and Etr pathways) which are primarily ISR type of responses. On the other hand, the red seaweed (Acanthophora spicifera) extract, induced the expression of the $P R$-1a gene at early stages (12-48 h after treatment), and when the level declined (at $48 \mathrm{~h}$ ), it led to the upregulation of the PinII and Etr-1 gene transcripts at later time points $(72-96 \mathrm{~h}$ ). This kind of harmonized modulation of pathways is a very interesting observation which was reported for the first time by these studies. These observations also demonstrated the obvious antagonistic activities of SA, JA, and ET pathways [133]. The brown seaweeds comprise of $17-45 \%$ alginates [134] and 5-20\% fucoidan [135] and laminarins, which have been linked to high bioactivity when applied to plants [9]. These major carbohydrate components of the brown seaweeds are known to negatively affect SA signaling $[136,137]$. This could be the reason for the low accumulation of the $P R-1$ a gene transcripts in brown seaweed extract treated plants. The studies by Ramkissoon et al. and Ali et al. [25,31] have confirmed that the main trigger of defense by brown seaweed extracts in plants was via the JA and ET mediated defense signaling pathways. However, the red seaweeds contain a variety of carrageenans [lambda $(\lambda)$, kappa $(\kappa)$ and iota $(\mathfrak{l}), \mathrm{mu}(\mu), \mathrm{nu}(\mathrm{v})$ and theta $(\theta)$ ], and all of them can act as elicitors [138] for SAR type responses. These carrageenans, which are not as sulfated, mainly elicit a SA defense-mediated signaling or systemic acquired resistance (SAR). Whereas the presence of higher levels of sulfated carrageenans can activate only induced systemic resistance (ISR)-type responses. These active polysaccharides present in seaweed extracts can elicit unique responses including upregulation of various PR proteins, defense genes and enzymes belonging to different pathways leading to the development of induced resistance and preconditioning of the plants. Therefore, compositional differences of seaweed extracts related to the species could be the plausible reason for the differential responses on defense pathway induction, as supported by previous studies [25,31].

The presence of anti-juvenile hormonal compounds in the seaweed (Padina pavonica) extract which significantly disrupted the cotton stainer bug (Dysdercus cingulatus) development stages at the germ bud or even at the stage of blastokineis [139]. Additionally, the phenolic compounds present in seaweed extracts were able to significantly reduce root knot nematode infestation in banana [140]. However, this is just a brief snapshot of the entire eliciting process of seaweed extracts and further studies are yet to be conducted to reveal the complexity of mechanisms.

Altogether, these results show the major properties associated with seaweed extracts, in that they cause elicitation of a cascade of metabolic networks to awaken in plants, thereby giving optimal protection against both biotic and abiotic stresses. Furthermore, it should also be stressed that these extracts perform better as a whole product rather than as fractions since the components interact together to produce synergies that act comprehensively on the plant system. Therefore, the observed effects are not due to a single defense pathway or a specific set of genes but due to the interaction of multiple genes in an organized, and harmonic fashion. 


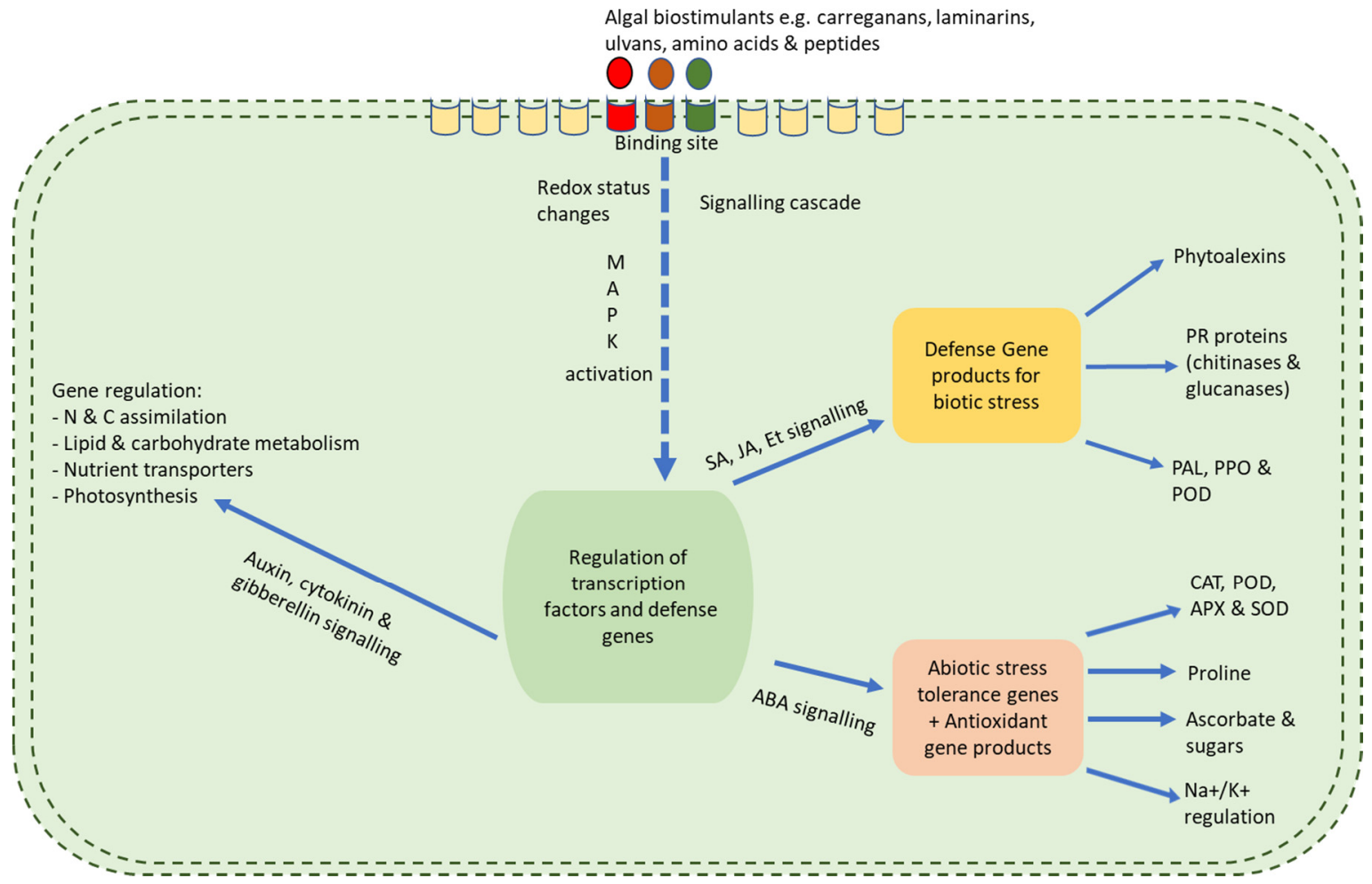

Figure 1. A schematic diagram outlining the mechanism of action of seaweed extract-based biostimulants. When the elicitor binds to the algal receptor sites, it leads to the activation of secondary messengers which causes a myriad of downstream processes [94]. After perception of an elicitor, reversible phosphorylation and dephosphorylation of the plasma membrane proteins and cytosolic proteins occur; this follows cytosolic $\left(\mathrm{Ca}^{2+}\right)$ enhancement; $\mathrm{Cl}^{-}$and $\mathrm{K}^{+}$efflux $/ \mathrm{H}^{+}$influx; alkalinization of the extracellular membrane and acidification of the cytoplasm with the activation of the mitogen-activated protein kinase (MAPK). Following MAPK activation, the production of reactive oxygen species (ROS) and reactive nitrogen species (RNS) occurs as well as NADPH oxidase initiation [137,141,142]. When this occurs, a cascade of chemical reactions in the plant which then allows for resistance and enhanced growth regulation.

\section{Effect of Seaweed Extracts on the Plant and Soil Microbiome Dynamics}

Plant surfaces including roots and leaves constitute the rhizosphere and phyllosphere where interactions between plant and microbes are highly active and vibrant. These microbial-based interactions have a profound influence on plant growth. Apart from external surfaces, the plant internal surfaces are also colonized by microorganisms wherein active interactions also significantly affect plant growth and productivity. Plant roots, leaves, and internal surfaces exude or release several water-soluble compounds such as amino acids, sugars, and organic acids, and these supports or influence the growth of a variety of microorganisms [143].

Application of biostimulants, fungicides, and other inputs over the foliage or soil has a significant influence on the exudate composition of the plant's external and internal surfaces. High levels of exudates in the rhizosphere activate a plethora of microorganisms. The composition and pattern of root exudates affect the population structure, size, and activity. As expected, the application of seaweed extracts to soil and foliage has significant effects on the rhizosphere and phyllosphere microbiome patterns. The healthy and productive growth of plants treated with seaweed extracts has also been suggested to be influenced by the microbiome effect conditioned by the extracts [10]. Therefore, seaweed extracts could potentially enhance PGP (plant growth promotion) traits of rhizospheric microbes.

A study was conducted on tomato and pepper plants in the greenhouse using Ascophyllum nodosum extract (ANE) to test its effect on bacterial and fungal communities in rhizospheric soils. Amplicon sequencing targeting fungal ITS and bacterial 16S rRNA genes to determine microbial community structure changes was conducted. The results 
showed a significant increase in plant growth parameters including root, shoot, and fruit biomass by ANE. Interestingly, the species composition of both fungi and bacteria on the roots and soil had significant variations (b-diversity) between the ANE treatment and the control. These variations were mostly inclined towards several beneficial groups of microbes growing in the rhizosphere, which could have had a significant influence on the growth of plants [144]. Similarly, when maize plants were applied with Ascophyllum nodosum-fermented seaweed fertilizer, there was a significant effect on the rhizosphere microbiome. The relative abundance of the dominant phyla varied, and the bacterial $\alpha$-diversity was significantly influenced by the seaweed fertilizer application. Additionally, the enzymatic activities of dehydrogenase, nitrite reductase, urease, and cellulase in the soil were significantly increased up to 13 days after the application of ANE to the maize rhizosphere soil. A seaweed extract biostimulant, based on Lessonia nigrescens and Lessonia flavicans applied to replant soil of Malus hupehensis seedlings, significantly increased the soil activity of invertase, urease, proteinase, and phosphatase enzymes in comparison with the control. T-RFLP analysis results showed that the soil fungal community had been significantly altered after the application of the seaweed extract [145]. The biolog analysis of the microbial metabolic activity of strawberry plants' rhizosphere soil, as well as functional diversity, colony counts, and soil respiration showed significant increases in response to Ascophyllum nodosum extract treatment under greenhouse and field conditions [132]. Although those effects are of major importance, the underlying microbiome effects and plant-microbiome interactions are largely under investigated. There is a growing need to use metagenomics tools to fully reveal the degree of microbial community discrepancy induced by seaweed extract application. These results will deepen our understanding of plant-microbe interactions in seaweed extract treatments and would help rationalize their use in sustainable agricultural production.

\section{Bioactive and Elicitor Components of Seaweed Extracts}

Seaweed extracts comprise of a wide array of bioactive substances that elicit and directly promote plant growth and defense reactions [3]. Some of these substances involved in various metabolic pathways include polysaccharides, plant growth-promoting hormones, fatty acids, sterols, carotenoids, oxylipins, minerals, peptides, amino acids and proteins, lipids, polyphenolics phlorotannins, all of which are biologically active $[3,16]$. These substances in the extracts vary differently based on the class and species of seaweed as well as the type of extraction method utilized.

Seaweeds contain many different polysaccharides, whose type, quantity, and chemical structure depends on the species of the seaweed and ecological conditions. Seaweeds normally contain polysaccharides up to $76 \%$ of dry weight but the content also shows seasonal variations. Among many different algal polysaccharides, the most important types are galactans, fucoidan, laminarin, and alginates, and most of these are proportionally represented in the seaweed extracts. The methods of extraction do have a great influence on the composition of the seaweed extracts. Normally during the extraction process, the complex molecules including polysaccharides are converted into oligomers which are highly bioactive in plants. In the same way, the small molecules like hormones may be significantly degraded [11]. Seaweed extracts contain different kinds of carotenoids, which are very strong antioxidants. The extracts also contain phenolic compounds including phenolic acids, flavonoids, isoflavones, cinnamic acid, benzoic acid, quercetin, and lignans. Algal extracts are known to contain various minerals since seaweeds basically bioaccumulate minerals found in the seawater. Seaweed extracts also have phytohormonic substances including cytokinins, gibberellins, auxins, abscisic acid, and betaines [142]. The effect of these substances on crops depends on the type of plant, its receptor mechanism, and the type of application used, specifically whether foliar, root feeding, or a combination of both [12]. Figure 2 and Table 3 highlight the important compounds present in seaweed extracts which all work harmoniously to promote plant growth and induce defense mechanisms. 




- Carbohydrates

- Protein

- Lipids

Minerals

Plant Growth regulators

Other

Figure 2. The estimated composition of seaweed extracts belonging to the three mega classes of seaweeds (red, green and brown).

Table 3. Major bioactive components of seaweed extracts.

\begin{tabular}{|c|c|c|c|c|}
\hline Bioactive Compounds & Chlorophyceae (Green) & Rhodophyceae (Red) & Phaeophyceae (Brown) & Reference \\
\hline Polysaccharides & $\begin{array}{ll}- & \text { Amylose, amylopectin } \\
- & \text { Cellulose } \\
- & \text { Glucomannans } \\
- & \text { Inulin } \\
- & \text { Laminaran } \\
- & \text { Ulvans } \\
- & \text { Sulfated mucilages } \\
- & \text { Xylans } \\
- & \text { Pectin } \\
- & \text { Mannans }\end{array}$ & $\begin{array}{ll}- & \text { Agars, agaroids } \\
- & \text { Cellulose } \\
- & \text { Mannans } \\
- & \text { Carrageenans } \\
- & \text { Complex mucilages } \\
- & \text { Furcellaran } \\
- & \text { Glycogen (floridean } \\
- & \text { starch) } \\
\text { - } & \text { Xylans } \\
\text { Rhodymanan }\end{array}$ & $\begin{array}{ll}- & \text { Alginates } \\
- & \text { Cellulose } \\
- & \text { Heteroglucans } \\
- & \text { Fucose } \\
- & \text { Fucoidans } \\
- & \text { Glucuronoxylofucans } \\
- & \text { Laminarans } \\
- & \text { Lichenan-like glucan }\end{array}$ & {$[55,137]$} \\
\hline Plant Growth Regulators & $\begin{array}{ll}- & \text { Cytokinins } \\
- & \text { Auxins } \\
- & \text { Gibberellins } \\
- & \text { Abscisic acid (ABA) } \\
- & \text { Indole-3-acetic } \\
& \text { acid (IAA) } \\
- & \text { Ethylene } \\
- & \text { Brassinosteroids } \\
- & \text { Jasmonates } \\
- & \text { Salicylic Acid } \\
- & \text { Strigolactones } \\
- & \text { Zeatin } \\
- & \text { Kinetin } \\
- & \text { 6-benzyl amino purine } \\
& \text { (BAP) }\end{array}$ & $\begin{array}{l}\text { Cytokinins } \\
\text { Auxins } \\
\text { Gibberellins } \\
\text { Abscisic acid (ABA) } \\
\text { Indole-3-acetic } \\
\text { acid (IAA) } \\
\text { Ethylene } \\
\text { Brassinosteroids } \\
\text { Jasmonates } \\
\text { Salicylic Acid } \\
\text { Strigolactones } \\
\text { Zeatin } \\
\text { Kinetin } \\
\text { 6-benzyl amino purine } \\
\text { (BAP) }\end{array}$ & $\begin{array}{l}\text { Cytokinins } \\
\text { Auxins } \\
\text { Gibberellins } \\
\text { Abscisic acid (ABA) } \\
\text { Indole-3-acetic } \\
\text { acid (IAA) } \\
\text { Ethylene } \\
\text { Brassinosteroids } \\
\text { Jasmonates } \\
\text { Salicylic Acid } \\
\text { Strigolactones } \\
\text { Zeatin } \\
\text { Kinetin } \\
\text { 6-benzyl amino purine } \\
\text { (BAP) }\end{array}$ & {$[16,146,147]$} \\
\hline Betaines & $\begin{array}{ll}- & \text { Glycine } \\
- & \gamma \text {-Aminobutyric acid } \\
- & \delta \text {-Aminovaleric acid } \\
- & \text { Laminine }\end{array}$ & $\begin{array}{l}\text { Glycine } \\
\gamma \text {-Aminobutyric acid } \\
\delta \text {-Aminovaleric acid } \\
\text { Laminine }\end{array}$ & $\begin{array}{l}\text { Glycine } \\
\gamma \text {-Aminobutyric acid } \\
\delta \text {-Aminovaleric acid } \\
\text { Laminine }\end{array}$ & {$[148,149]$} \\
\hline Sterols & $\begin{array}{ll}- & \text { Ergosterol } \\
- & \text { Isofucosterol } \\
- & \text { Clerosterol } \\
- & \text { Clionasterol }\end{array}$ & $\begin{array}{ll}- & \text { Cholesterol } \\
- & \text { Cholesterol derivatives } \\
- & \text { Fucosterol } \\
- & \beta \text {-sitosterol } \\
- & \text { Campesterol }\end{array}$ & $\begin{array}{l}\text { Fucosterol } \\
\text { Fucosterol derivatives } \\
\text { Cholesterol } \\
\text { Campesterol } \\
\text { Stigmasterol }\end{array}$ & [150-153] \\
\hline
\end{tabular}


Table 3. Cont.

\begin{tabular}{|c|c|c|c|c|}
\hline Bioactive Compounds & Chlorophyceae (Green) & Rhodophyceae (Red) & Phaeophyceae (Brown) & Reference \\
\hline Carotenoid & $\begin{array}{ll}- & \beta \text {-carotene } \\
- & \text { Lutein } \\
- & \text { Violaxanthin } \\
- & \text { Antheraxanthin } \\
- & \text { Zeaxanthin } \\
- & \text { Neoxanthin }\end{array}$ & $\begin{array}{l}\beta \text {-carotene } \\
\alpha \text {-carotene } \\
\text { Zeaxanthin } \\
\text { Lutein }\end{array}$ & $\begin{array}{l}\text { Fucoxanthin } \\
\beta \text {-carotene } \\
\text { Violaxanthin }\end{array}$ & {$[154,155]$} \\
\hline Minerals & $\begin{array}{l}\text { Macro (C, Cl, Fe, Mg, P, } \\
\text { K, Na and S) } \\
\text { Micro (B, Cr, Co, Cu, F, } \\
\text { Gr, I, Mn, Mo, Ni, Se, Si, } \\
\text { S, Tn, W, V, Zn) }\end{array}$ & $\begin{array}{l}\text { Macro (C, Cl, Fe, Mg, P, } \\
\text { K, Na and S) } \\
\text { Micro (B, Cr, Co, Cu, F, } \\
\text { Gr, I, Mn, Mo, Ni, Se, Si, } \\
\text { S, Tn, W, V, Zn) }\end{array}$ & $\begin{array}{l}\text { Macro (C, Cl, Fe, Mg, P, } \\
\text { K, Na and S) } \\
\text { Micro (B, Cr, Co, Cu, F, } \\
\text { Gr, I, Mn, Mo, Ni, Se, Si, } \\
\text { S, Tn, W, V, Zn) }\end{array}$ & [156-158] \\
\hline $\begin{array}{l}\text { Polyphenolics and } \\
\text { Phlorotannins }\end{array}$ & $\begin{array}{l}\text { Bromophenols } \\
\text { Flavonoids }\end{array}$ & $\begin{array}{l}\text { Bromophenols } \\
\text { Flavonoids } \\
\text { Phenolic terpenoids } \\
\text { Mycosporine-like amino } \\
\text { Acid }\end{array}$ & $\begin{array}{ll}- & \text { Bromophenols } \\
- & \text { Flavonoids } \\
- & \text { Phenolic terpenoids } \\
- & \text { Phloroglucinol } \\
- & \text { Eckol } \\
- & \text { Dieckol }\end{array}$ & {$[159,160]$} \\
\hline Lipids & $\begin{array}{ll}\text { - } & \text { Glycolipids } \\
\text { - } & \text { Betaine lipids } \\
\text { - } & \text { Non-polar glycerolipids } \\
& \text { (neutral lipids) } \\
\text { - } & \text { Mannose and rhamnose } \\
& \text { containing glycolipids }\end{array}$ & $\begin{array}{ll}\text { - } & \text { Sulfur-containing } \\
\text { phospholipids }\end{array}$ & $\begin{array}{ll}- & \text { Glycolipids } \\
- & \text { Betaine lipids } \\
- & \text { Non-polar glycerolipids } \\
& \text { (neutral lipids) } \\
\text { - } & \text { Unusual lipid class }\end{array}$ & {$[153,161,162]$} \\
\hline Oxylipins & $\begin{array}{ll}- & \begin{array}{l}\text { Hydroxy and } \\
\text { hydroperoxy fatty acids }\end{array} \\
\text { - } & \text { (FAs) Coalital } \\
\text { (C10-oxylipin) } \\
\text { - } \quad \text { Epoxy alcohol } \\
-\quad \text { Hydroxy and } \\
\text { hydroperoxy FAs } \\
\text { 13-oxo-trideca-9,11- } \\
\text { dienoic acid, } \\
\text { (2Z) } \\
\text { pentane, pentanol, } \\
\text { hexanal }\end{array}$ & $\begin{array}{ll}- & \text { Hydroperoxy FAs } \\
- & \text { Hydroxy FAs } \\
- & \text { Diols } \\
- & \text { Epoxy FAs } \\
- & \text { Prostaglandins } \\
- & \text { Leukotrienes } \\
- & \text { Cyclopropyl } \\
& \text { hydroxyeicosanoids } \\
- & \text { Eicosanoids } \\
- & \text { Hepoxilin like } \\
& \text { metabolite } \\
- & \text { Polyneuric acid }\end{array}$ & $\begin{array}{ll}\text { - } & \text { Ecklonialactones } \\
- & \text { Egregialactones } \\
- & \text { Carbocyclic } \\
\text { eiseniachlorides, } \\
\text { eiseniaiodides } \\
\text { and bicyclic cymathere } \\
\text { ethers } \\
\text { - } \quad \text { Hydroxy-, hydroperoxy } \\
\text { FAs }\end{array}$ & {$[151,160-163]$} \\
\hline $\begin{array}{l}\text { Protein, peptides, and } \\
\text { amino acids }\end{array}$ & 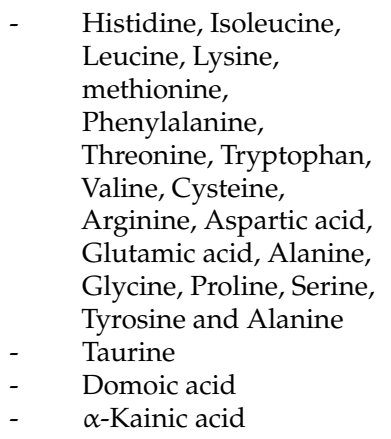 & $\begin{array}{l}\text { Histidine, Isoleucine, } \\
\text { Leucine, Lysine, } \\
\text { methionine, } \\
\text { Phenylalanine, } \\
\text { Threonine, Tryptophan, } \\
\text { Valine, Cysteine, } \\
\text { Arginine, Aspartic acid, } \\
\text { Glutamic acid, Alanine, } \\
\text { Glycine, Proline, Serine, } \\
\text { Tyrosine and Alanine } \\
\text { Taurine } \\
\text { Domoic acid } \\
\alpha \text {-Kainic acid }\end{array}$ & $\begin{array}{l}\text { - } \\
\text { Leustidine, Isoleucine, } \\
\text { methionine, } \\
\text { Phenylalanine, } \\
\text { Threonine, Tryptophan, } \\
\text { Valine, Cysteine, } \\
\text { Arginine, Aspartic acid, } \\
\text { Glutamic acid, Alanine, } \\
\text { Glycine, Proline, Serine, } \\
\text { Tyrosine and Alanine } \\
\text { - Taurine } \\
\text { - } \alpha \text {-Kainic acid }\end{array}$ & [164-166] \\
\hline
\end{tabular}

\section{Seaweed Extract as an Input for Integrated Crop Management Program: A Paradigm Shift towards Sustainable Agriculture}

Due to the intensification of agriculture globally, there is a heavy reliance on the use of synthetic chemical inputs in agriculture. Most of these synthetic chemical inputs used however have their drawbacks, especially when overused. Although optimum usage leads to overall higher returns, it can cause toxic and long-lasting unfavorable effects on the environment and humans, especially by improper and over-usage. These drawbacks may 
cause an increase in pesticide resistance, run-off into the environment causing serious problems such as eutrophication, water contamination, leftover residue causing harm to humans and animals, and overall increases in production costs [167]. Apart from those effects, there is the added danger of non-target effects. Studies have shown that constant overuse of pesticides and chemical fertilizers has led to the downfall of non-target beneficial organisms which ultimately affects the entire food chain, thereby affecting overall diversity [168]. The World Health Organization (WHO) reports approximately 25 million cases of acute occupational pesticide poising in developing countries [169]. Many of these pesticides are now being tightly regulated, especially in developed countries since studies have shown their high persistence in the environment and highly toxic effects on humans such as carcinogenicity, hormonal imbalances, spermatotoxicity, teratogenicity $[170,171]$.

Many countries have come forward with initiatives to minimize the persistent ill effects of chemicals in agriculture by imposing laws and implementing intensive management programs. These include basically integrated management methods wherein application of synthetic chemicals is kept at a minimum, and more emphasis is given to enhance natural systems of protection using natural enemies and non-chemical, biological, and organic inputs [172]. This is the era wherein implementation of holistic approaches or systems including integrated crop management (ICM), integrated nutrient management (INM), integrated disease management (IDM), an integrated pest management (IPM) are under imperative practice [173].

In light of the integrated management methods, scientists and farmers alike are looking for ecologically safe alternatives, one of which in the forefront is seaweed extract biostimulants/products [172]. The previous chapters highlighted the positive impacts of seaweed extracts on the overall net return of crops. The integrated management approach in agriculture aims at applying more than one method in order to control disease outbreaks in crops, and by that, the use of seaweed extracts could be a preferred component due to its multiple modes of action. Their non-toxic nature and multiple beneficial roles to the crop and environment are the major highlights for being considered as green inputs. Feasibility studies have shown that farmers are willing to use seaweed extracts and products as "green alternatives" within their existing cropping scheme [13]. New studies have shown that farmers who used less than half their usual chemical inputs per crop in conjunction with seaweed extract, received higher returns from the produce. Studies done in the tropics showed that sweet pepper and tomato plants treated with extracts of either A. nodosum, S. vulgare, or A. spicifera in rotation with safe fungicides had the lowest disease levels and the overall highest total marketable yield compared to treatments with seaweed extract alone or fungicide alone. It has been speculated that this positive effect of seaweed extracts could have been a result of their multiple beneficial actions on the crop host ultimately leading to lower disease and pest levels and greater yields $[4,28,31]$.

A five year-long research study by UWI-St. Augustine entitled, "Developing sustainable disease management strategies to improve vegetable production towards selfsufficiency and food security in the Caribbean region" utilized many aspects of IDM components in which seaweed extracts were used as a prominent input. The results showed that integrating various inputs in the cultivation of tomato, pumpkin, pepper, and cowpea lead to significant reductions of major diseases as well as significant improvements in the total marketable yield and while reducing the incidence of pests and diseases [174]. These studies, therefore, demonstrated and certified the essential role of seaweed extract spray as an organic component for widespread use in crops. By increasing the rate of use of seaweed extracts and other organic inputs, the standard rate of application of chemicals was reduced by two-thirds without negatively impacting yields [10]. Most of the seaweedbased products are classified as biostimulants, organic nutrients, or plant boosters and were considered as organic inputs. This contributes to the extensive use of seaweed products to crops certified for organic production as well as environmental-friendly production or for regular use under integrated crop management systems [12,174]. 


\section{Challenges and Opportunities for Seaweed Biomass Valorization and Development of Novel Agricultural Inputs}

The utilization of seaweed biomass as a resource for deriving novel products for use in agricultural industries, while appears challenging, has however created a fair number of opportunities for scientific knowledge generation and innovation. Though seaweeds are a highly renewable biomass, generally, there are significant challenges in harvesting, processing, and storage of seaweed biomass. Additionally, seasonal growth and inflow of seaweed biomass force industries to focus on efficient harvesting techniques, quick processing, and storage methods. Sustainable harvesting methods have been developed and proven successful for brown kelp, and, therefore, there is a great need for optimizing the harvesting of other important seaweeds. For the well-known kelp species, efficient harvesting of biomass during growth seasons has helped preserve the native growth and ecological biodiversity. Further to this, wet and dry processing and preservation methods were optimized for efficient processing, storage, extraction, and biotransformation [175].

There are various extraction protocols developed which employ physical and chemical methods to efficiently extract the biomolecules with minimum loss to their conformation and bioactivity [122]. The active molecules can either be purified or used as whole extracts for agricultural purposes. Many biostimulant based formulations have been developed using seaweed extract as a component or as the complete ingredient [14]. But still, extraction protocols need to be optimized for some of the promising seaweeds. With regard to formulations, there are only liquid, dispersible, and soluble solids available. Not many successful efforts have been reported for developing novel commercial formulations for use in traditional and protected crop production systems. Further, developing composite formulations or value-added formulations incorporating a mixture of seaweeds, other biological components including live microorganisms, plant extracts, and biopesticides is still a technological gap that needs to be bridged [12].

While there are several potential beneficial effects of seaweed products, contrastingly there are also some undesirable side effects posed by the seaweed-based products which need to be carefully dealt upfront. For instance, the contamination of seaweed biomass by heavy metals and persistent organic pollutants threaten their widespread use in agricultural applications [176]. Many of the seaweeds tend to absorb pollutants normally found in the substrate water. Excessive contamination by pollutants can challenge their use for processing and extensive applications in agriculture. Therefore, technologies are being developed for clarification of pollutants prior to or after processing $[177,178]$.

The imposition of strict quality requirements on seaweed biomass is not practically feasible for agricultural products including extracts and composts. This is due to the inherent variations in the species, their growth habits, and habitats, geographical location, environmental and climatic conditions. It is, therefore, quite hard to maintain consistent quality as pure seaweed extract is fully biological. Quality could only be optimized by blending batches of extracts and by necessarily adding adjuvants without compromising their biological status and label. Often, the seaweed products, particularly liquid formulations become less stable over time. This difficulty needs to be addressed by finding suitable stabilizers and additives to enhance the shelf life and stability of quality.

Seaweed products used in agriculture are generally proven environmentally safe and considered to be organic components, if the formulation contains a maximum level of natural ingredients. However, there are also several spurious products circulating in the market in the name of "seaweed organic biostimulants" which contain only a small fraction of seaweed-derived components but comprise mainly of synthetic mineral nutrients and chemicals. These were being sold as biofertilizers or biostimulants which creates confusion among users. This mandates imposition of strict quality standards to correctly identify, certify, and label products with the originality of their organic composition.

Though the seaweed extracts evoke multiple responses in plants to counter biotic and abiotic stresses, much of the genetic, physiological, and biochemical mechanisms are yet to be unraveled, which requires comprehensive and systematic research investigations. Fur- 
ther, most of the research tends to be focused on greenhouse and controlled environment trials. Rigorous experimentation at the field level and data collection at multi-crop, multiseasonal, multi-locational and geographical situations are needed before recommendation to growers. The delivery of seaweed products is currently predominantly limited to foliar and soil application. Soil application is often expensive as it requires high levels and multiple applications, which is a limitation. Methods of the application still need to be worked out which favors optimal applications without burdening the overall cost of production. There are also some challenges in labeling the seaweed extract-based formulations due to their multiple activities and functions. The use of labels "biostimulant/biofertilizer" for seaweed extracts are becoming obsolete or out of context given their multiple activities. This creates practical difficulty in the classification of products in the commercial sense. In terms of usage, seaweed extract should be considered as an input suitable for integration and complementation with other inputs used in agriculture. This also requires extensive field-based integrated crop production evaluation trials in each crop in different seasons and locations. Ideally, the use of seaweed extracts should minimize the application of chemical inputs and thereby vertically reducing the chemical load and cost [13].

The seaweed biomass can provide a rich resource for multiple applications and each one of them has matured into industries with a high level of contribution to the micro and macroeconomy. The extracts apart from their phytostimulant value, they act as a resource for the extraction of value-added biomolecules including polysaccharides and several industrial, pharmaceutical, nutraceutical, feed, and food supplements and products. The final residue after extraction can be used as a soil amendment, animal feed supplement, compost base, planting mix, biochar base, or even construction materials (ex. particleboard, concrete, etc.) [179]. Therefore, seaweed biomass is an excellent resource for developing multiple products that are both environmentally neutral and sustainable thereby promoting recyclability and a circular methodology and circular economy.

Since seaweed biomass accumulation and bycatch happens at shallow marine habitats of countries with a sea line, anglers and the beachline communities are the mainly affected parties. The recent surge in Sargassum accumulation in the Caribbean region, particularly in the island states, has resulted in many of these countries incurring significant losses to their tourist economy [180]. However, the development of successful and sustainable methods for the valorization of the biomass of Sargassum and other seaweeds could generate diverse opportunities for multiple economic activities. The methods so far developed can offer some solution to this problem. In this way, the serious ecological problem of seaweed biomass accumulation can be collectively managed by proper resource utilization and transformation of biomass [10]. The fishermen and the beach communities can be employed or involved in biomass collection and bioprocessing in a systematic manner. These ideas hold promise for developing small cooperative or community-based industries as well as larger-scale operations involved in processing and valorization of seaweeds for deriving multiple products through circular economy.

\section{Conclusions}

Generally, the positive impacts of seaweed extract-based biostimulants on crop production and the environment warrant their prescription for applications in different cropping systems. Published reports so far confirmed the positive effects on plant growth, vigor, enhanced tolerance to pests, diseases, and abiotic stresses, as well as an overall improvement in plant productivity. The summary of the effects of seaweed extracts on crops is depicted in Figure 3. Published reports also highlighted the improvement in the nutritional quality of seaweed extract treated crops including increased antioxidant contents, which enhances the attractiveness of seaweed products for use in crop production. The positive effects of the seaweed products are dependent on the type of the seaweed resource, quality, and composition of the extract, and the method, concentration, and frequency of application. All the enhanced growth effects have been observed only with the whole extract, which underlines the very interactive nature and synergistic activity of the seaweed extract components 
on plant growth and functions. However, the synergistic activities and interactions of biomolecules and their molecular functions on the plants are largely unresolved due to its complexity. There is strong evidence to support the role of seaweed extract applications in altering the microbiome of the rhizosphere and phyllosphere. Further studies into this area should verify the effect of introduced and native beneficial microbes in order to improve the microbial plant growth promotion. There is also a necessity to understand the basic level of communication between the plant and microbial systems' interface as influenced by seaweed extracts. Emerging studies also support the compatibility of seaweed extracts and products with other agricultural chemical and non-chemical inputs. Although using seaweed extract as a sole input or standalone method may not be sustainable, it is ideal to use a minimum dose of pesticides which can synergize the seaweed effects and benefit the overall crop production phenomenon. The seaweed extract formulations are available as liquid concentrates which limits their shelf life. Efforts are needed to produce user-friendly and stable solid formulations that can have improved shelf-life. The soil application of seaweed extract remains economically challenging due to the high levels of input needed. Alternative means including root feeding, foliar misting, and drip application need to be optimized for the crops and growing systems. Although seaweed biomass is renewable, due care should be taken to prevent over-exploitation and disturbance to the marine or coastal biodiversity. The recent excessive inflow of Sargassum weed in the pacific and Atlantic currents are posing serious challenges to the marine and coastal biodiversity. Methods for valorisation and transformation of this seaweed into value added and novel products are still at the stages of infancy. On the other count, commercial culturing of economically important seaweeds for development of novel biostimulants or commercial products would be essential in order to conserve the seaweed resources and prevent overuse and extinction from their natural ecosystems. Considering the current focus and necessity for organic and environmentally sensible agriculture, the need for more effective organic inputs is ever growing. Being renewable bioresources, seaweeds and their bioproducts can certainly provide multiple organic inputs to the levels to meet the ever-growing crop needs. Research and development, therefore, should continue in these directions to maximize the potential utility of seaweeds and their products in sustainable agriculture. 


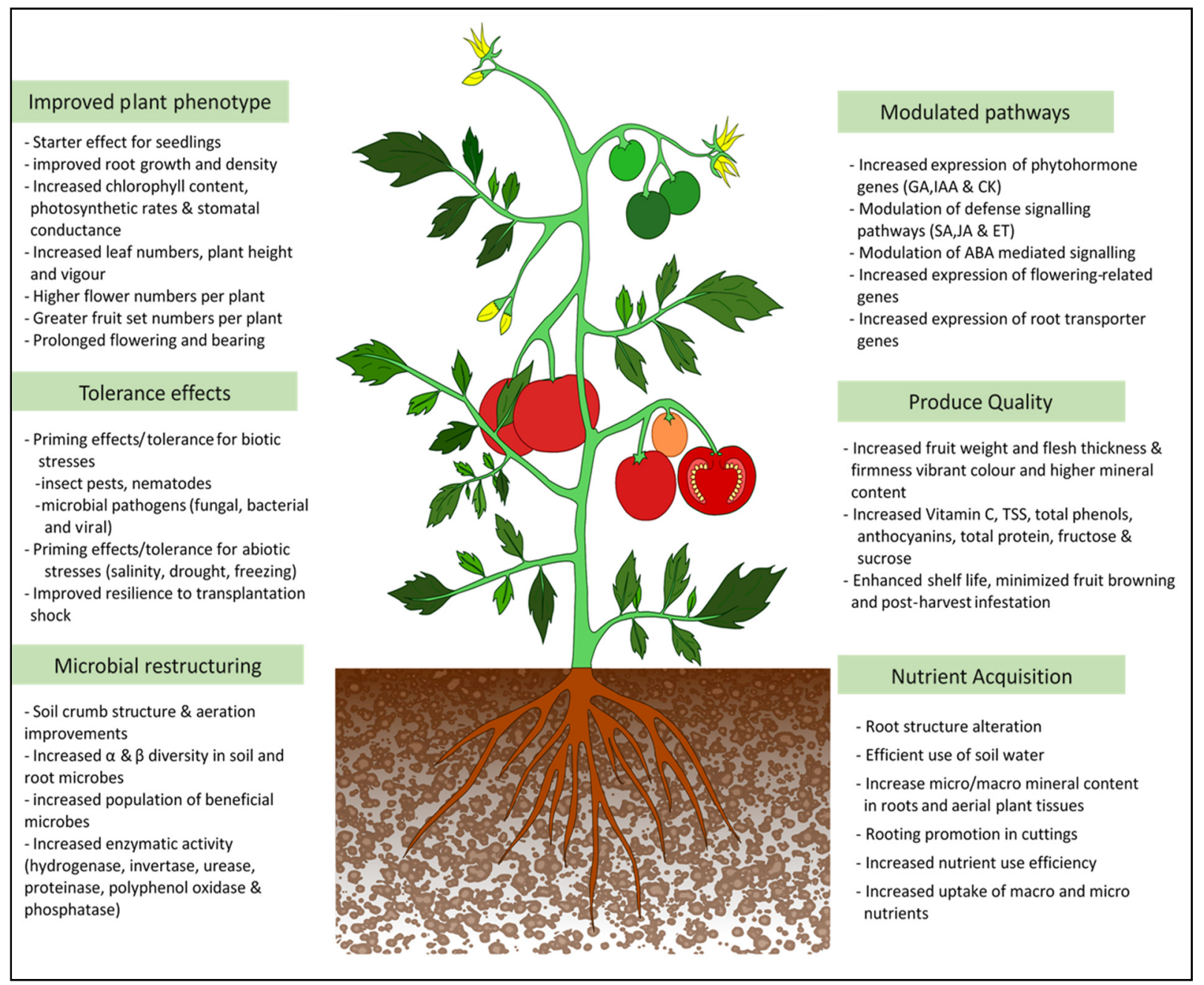

Figure 3. Overview of the positive effects of seaweed extracts on the plant and soil systems.

Funding: The preparation of this manuscript was funded by the RDI-IPOC Research Grant, UWI, and Govt. of Trinidad and Tobago to J.J. and A.R.

Conflicts of Interest: The authors declare no conflict of interest.

\section{References}

1. Yakhin, O.I.; Lubyanov, A.A.; Yakhin, I.A.; Brown, P.H. Biostimulants in Plant Science: A Global Perspective. Front. Plant Sci. 2017, 54, 23-27. [CrossRef]

2. Du Jardin, P. The Science of Plant Biostimulants-A Bibliographic Analysis, Ad Hoc Study Report; European Commission: Brussels, Belgium, 2012.

3. Khan, W.; Rayirath, U.P.; Subramanian, S.; Jithesh, M.N.; Rayorath, P.; Hodges, D.M.; Critchley, A.T.; Craigie, J.S.; Norrie, J.; Prithiviraj, B. Seaweed Extracts as Biostimulants of Plant Growth and Development. J. Plant Growth Regul. 2009, 45, 112-134. [CrossRef]

4. Du Jardin, P. Plant Biostimulants: Definition, Concept, Main Categories and Regulation. Sci. Hortic. (Amst. ) 2015, 53, 3555-3654. [CrossRef]

5. Ali, O.; Ramsubhag, A.; Jayaraman, J. Biostimulatory Activities of Ascophyllum nodosum Extract in Tomato and Sweet Pepper Crops in a Tropical Environment. PLoS ONE 2019, 14, e0216710. [CrossRef] [PubMed]

6. Kapur, B.; Sarıdaş, M.A.; Çeliktopuz, E.; Kafkas, E.; Paydaş Karg1, S. Health and Taste Related Compounds in Strawberries under Various Irrigation Regimes and Bio-Stimulant Application. Food Chem. 2018. [CrossRef] [PubMed]

7. Li, Y.; Mattson, N.S. Effects of Seaweed Extract Application Rate and Method on Post-Production Life of Petunia and Tomato Transplants. Horttechnology 2015. [CrossRef]

8. Parađiković, N.; Teklić, T.; Zeljković, S.; Lisjak, M.; Špoljarević, M. Biostimulants Research in Some Horticultural Plant Species-A Review. Food Energy Secur. 2019. [CrossRef] 
9. Shukla, P.S.; Mantin, E.G.; Adil, M.; Bajpai, S.; Critchley, A.T.; Prithiviraj, B. Ascophyllum nodosum -Based Biostimulants: Sustainable Applications in Agriculture for the Stimulation of Plant Growth, Stress Tolerance, and Disease Management. Front. Plant Sci. 2019. [CrossRef] [PubMed]

10. Jayaraj, J. Induced Resistance-a Sustainable Biotechnological Approach of Plant Disease Management. In Microbial Antagonists: Their Role in Biological Control of Plant Diseases; Today \& Tomorrow's Printers and Publishers: New Delhi, India, 2018; pp. 770-777.

11. Jayaraman, J.; Ali, N. Use of Seaweed Extracts for Disease Management of Vegetable Crops. In Sustainable Crop Disease Management Using Natural Products; CABI: Wallingford, UK, 2015; pp. 160-173.

12. Ali, N.; Farrell, A.; Ramsubhag, A.; Jayaraman, J. The Effect of Ascophyllum nodosum Extract on the Growth, Yield and Fruit Quality of Tomato Grown under Tropical Conditions. J. Appl. Phycol. 2016, 28, 1353-1362. [CrossRef]

13. Ali, O.; Ramsubhag, A.; Jayaraman, J. Phytoelicitor Activity of Sargassum vulgare and Acanthophora spicifera Extracts and Their Prospects for Use in Vegetable Crops for Sustainable Crop Production. J. Appl. Phycol. 2020. [CrossRef]

14. Arioli, T.; Mattner, S.W.; Winberg, P.C. Applications of Seaweed Extracts in Australian Agriculture: Past, Present and Future. J. Appl. Phycol. 2015, 27, 2007-2015. [CrossRef]

15. Rayorath, P.; Khan, W.; Palanisamy, R.; Mackinnon, S.L.; Stefanova, R.; Hankins, S.D.; Critchley, A.T.; Prithiviraj, B. Extracts of the Brown Seaweed Ascophyllum nodosum Induce Gibberellic Acid (GA3)-Independent Amylase Activity in Barley. J. Plant Growth Regul. 2008, 32, 123-128. [CrossRef]

16. Crouch, I.J.; van Staden, J. Evidence for the Presence of Plant Growth Regulators in Commercial Seaweed Products. Plant Growth Regul. 1993, 6, 345-388. [CrossRef]

17. Aldworth, S.J.; van Staden, J. The Effect of Seaweed Concentrate on Seedling Transplants. S. Afr. J. Bot. 1987. [CrossRef]

18. Crouch, I.J.; Smith, M.T.; van Staden, J.; Lewis, M.J.; Hoad, G.V. Identification of Auxins in a Commercial Seaweed Concentrate. J. Plant Physiol. 1992. [CrossRef]

19. Crouch, I.J.; Van Staden, J. Evidence for Rooting Factors in a Seaweed Concentrate Prepared from Ecklonia maxima. J. Plant Physiol. 1991. [CrossRef]

20. Atzmon, N.; Van Staden, J. The Effect of Seaweed Concentrate on the Growth of Pinus pinea Seedlings. New For. 1994. [CrossRef]

21. Leclerc, M.; Caldwell, C.D.; Lada, R.R.; Norrie, J. Effect of Plant Growth Regulators on Propagule Formation in Hemerocallis spp. and Hosta spp. HortScience 2006. [CrossRef]

22. Crouch, I.J.; Beckett, R.P.; van Staden, J. Effect of Seaweed Concentrate on the Growth and Mineral Nutrition of Nutrient-Stressed Lettuce. J. Appl. Phycol. 1990. [CrossRef]

23. Senthuran, S.; Balasooriya, B.L.W.K.; Arasakesary, S.J.; Gnanavelrajah, N. Effect of Seaweed Extract Kappaphycus alvarezii on the Growth, Yield and Nutrient Uptake of Leafy Vegetable Amaranthus Polygamous. Trop. Agric. Res. 2019. [CrossRef]

24. Ertani, A.; Francioso, O.; Tinti, A.; Schiavon, M.; Pizzeghello, D.; Nardi, S. Evaluation of Seaweed Extracts from Laminaria and Ascophyllum nodosum Spp. As Biostimulants in Zea mays L. Using a Combination of Chemical, Biochemical and Morphological Approaches. Front. Plant Sci. 2018. [CrossRef] [PubMed]

25. Fei, H.; Crouse, M.; Papadopoulos, Y.; Vessey, J.K. Enhancing the Productivity of Hybrid Poplar (Populus $\times$ Hybrid) and Switchgrass (Panicum virgatum L.) by the Application of Beneficial Soil Microbes and a Seaweed Extract. Biomass Bioenergy 2017. [CrossRef]

26. Di Stasio, E.; Rouphael, Y.; Colla, G.; Raimondi, G.; Giordano, M.; Pannico, A.; El-Nakhel, C.; De Pascale, S. The Influence of Ecklonia maxima Seaweed Extract on Growth, Photosynthetic Activity and Mineral Composition of Brassica rapa L. ssp. sylvestris under Nutrient Stress Conditions. Eur. J. Hortic. Sci. 2017. [CrossRef]

27. Werner, T.; Motyka, V.; Strnad, M.; Schmülling, T. Regulation of Plant Growth by Cytokinin. Proc. Natl. Acad. Sci. USA 2001. [CrossRef]

28. Blunden, G.; Jenkins, T.; Liu, Y.W. Enhanced Leaf Chlorophyll Levels in Plants Treated with Seaweed Extract. J. Appl. Phycol. 1996, 3, 13-19. [CrossRef]

29. Whapham, C.A.; Blunden, G.; Jenkins, T.; Hankins, S.D. Significance of Betaines in the Increased Chlorophyll Content of Plants Treated with Seaweed Extract. J. Appl. Phycol. 1993. [CrossRef]

30. Genard, H.; Le Saos, J.; Billard, J.; Tremolieres, A.; Boucaud, J. Effect of Salinity on Lipid Composition, Glycine Betaine Content and Photosynthetic Activity in Chloroplasts of Suaeda maritima. Plant Physiol. Biochem. 1991, 29, 421-427.

31. Al-Ghamdi, A.A.; Elansary, H.O. Synergetic Effects of 5-Aminolevulinic Acid and Ascophyllum nodosum Seaweed Extracts on Asparagus Phenolics and Stress Related Genes under Saline Irrigation. Plant Physiol. Biochem. 2018. [CrossRef] [PubMed]

32. Digruber, T.; Sass, L.; Cseri, A.; Paul, K.; Nagy, A.V.; Remenyik, J.; Molnár, I.; Vass, I.; Toldi, O.; Gyuricza, C.; et al. Stimulation of Energy Willow Biomass with Triacontanol and Seaweed Extract. Ind. Crop. Prod. 2018. [CrossRef]

33. Ramkissoon, A.; Ramsubhag, A.; Jayaraman, J. Phytoelicitor Activity of Three Caribbean Seaweed Species on Suppression of Pathogenic Infections in Tomato Plants. J. Appl. Phycol. 2017, 34, 123-129. [CrossRef]

34. Dookie, M.; Ali, O.; Ramsubhag, A.; Jayaraman, J. Flowering Gene Regulation in Tomato Plants Treated with Brown Seaweed Extracts. Sci. Hortic. (Amst. ) 2020. [CrossRef]

35. El-Yazied, A.; El-Gizawy, A.M.; Ragab, M.I.; Hamed, E.S. Effect of Seaweed Extract and Compost Treatments on Growth, Yield and Quality of Snap Bean. J. Am. Sci. 2012, 8, 1-20. 
36. Kulkarni, M.G.; Rengasamy, K.R.R.; Pendota, S.C.; Gruz, J.; Plačková, L.; Novák, O.; Doležal, K.; Van Staden, J. Bioactive Molecules Derived from Smoke and Seaweed Ecklonia maxima Showing Phytohormone-like Activity in Spinacia oleracea L. N. Biotechnol. 2019. [CrossRef] [PubMed]

37. Yusuf, R.; Kristianse, P.; Warwick, N. Effect of Two Seaweed Products and Equivalent Mineral Treatments on Lettuce (Lactuca sativa L.) Growth. J. Agron. 2019. [CrossRef]

38. Xu, C.; Leskovar, D.I. Effects of A. nodosum Seaweed Extracts on Spinach Growth, Physiology and Nutrition Value under Drought Stress. Sci. Hortic. (Amst.) 2015, 183, 39-47. [CrossRef]

39. Valencia, R.T.; Acosta, L.S.; Hernández, M.F.; Rangel, P.P.; Gallegos Robles, M.Á.; del Carmen Antonio Cruz, R.; Vázquez, C.V. Effect of Seaweed Aqueous Extracts and Compost on Vegetative Growth, Yield, and Nutraceutical Quality of Cucumber (Cucumis satious L.) Fruit. Agronomy 2018, 8, 264. [CrossRef]

40. Frioni, T.; Sabbatini, P.; Tombesi, S.; Norrie, J.; Poni, S.; Gatti, M.; Palliotti, A. Effects of a Biostimulant Derived from the Brown Seaweed Ascophyllum nodosum on Ripening Dynamics and Fruit Quality of Grapevines. Sci. Hortic. (Amst.) 2018. [CrossRef]

41. Augusto, A.; Simões, T.; Pedrosa, R.; Silva, S.F.J. Evaluation of Seaweed Extracts Functionality as Post-Harvest Treatment for Minimally Processed Fuji Apples. Innov. Food Sci. Emerg. Technol. 2016. [CrossRef]

42. Finnie, J.F.; van Staden, J. Effect of Seaweed Concentrate and Applied Hormones on In Vitro Cultured Tomato Roots. J. Plant Physiol. 1985. [CrossRef]

43. Beckett, R.P.; van Staden, J. The Effect of Seaweed Concentrate on the Growth and Yield of Potassium Stressed Wheat. Plant Soil 1989, 53, 187-189. [CrossRef]

44. Vernieri, P.; Borghesi, E.; Tognoni, F.; Serra, G.; Ferrante, A.; Piaggesi, A. Use of Biostimulants for Reducing Nutrient Solution Concentration in Floating System. Acta Hortic. 2006, 21, 123-134. [CrossRef]

45. Mancuso, S.; Azzarello, E.; Mugnai, S.; Briand, X. Marine Bioactive Substances (IPA Extract) Improve Foliar Ion Uptake and Water Stress Tolerance in Potted Vitis vinifera Plants. Adv. Hortic. Sci. 2006. [CrossRef]

46. Ayliffe, M.A.; Lagudah, E.S. Molecular Genetics of Disease Resistance in Cereals. Ann. Bot. 2004. [CrossRef] [PubMed]

47. Anderson, P.K.; Cunningham, A.A.; Patel, N.G.; Morales, F.J.; Epstein, P.R.; Daszak, P. Emerging Infectious Diseases of Plants: Pathogen Pollution, Climate Change and Agrotechnology Drivers. Trends Ecol. Evol. 2004. [CrossRef]

48. De Waele, D.; Mcdonald, H.; De Waele, E. Influence of Seaweed Concentrate on the Reproduction of Pratylenchuszeae (Nematoda) on Maize. Nematologica 1988. [CrossRef]

49. Asaraja, A.; Sahayaraj, K. Screening of Insecticidal Activity of Brown Macroalgal Extracts against Dysdercus cingulatus (Fab.) (Hemiptera: Pyrrhocoridae). J. Biopestic. 2013, 6, 193-203.

50. Gençsoylu, İ. Effect Of Seaweeds And Organic Foliar Fertilizers On The Cotton Pests, Predators, Yield And Fiber Quality In Cotton. Adnan Menderes Üniv. Ziraat Fakültesi Derg. 2016. [CrossRef]

51. González-Castro, A.L.; Muñoz-Ochoa, M.; Hernández-Carmona, G.; López-Vivas, J.M. Evaluation of Seaweed Extracts for the Control of the Asian Citrus Psyllid Diaphorina citri. J. Appl. Phycol. 2019. [CrossRef]

52. Carolina Feitosa de Vasconcelos, A.; Helena Garófalo Chaves, L. Biostimulants and Their Role in Improving Plant Growth under Abiotic Stresses. In Biostimulants in Plant Science; IntechOpen: London, UK, 2019.

53. Chen, D.; Huang, Y.; Shen, D.; Zhou, W.; Ao, J.; Jiang, Y.; Huang, Z.; Hassan, M.; Fahd, R. Effects of Seaweed Extracts on Promoting Growth and Improving Stress Resistance in Sugarcane. Asian Agric. Res. 2019, 69-76. [CrossRef]

54. Kubo, I.; Matsumoto, T.; Ichikawa, N. Absolute Configuration Of Crinitol. An Acyclic Diterpene Insect Growth Inhibitor From The Brown Algae Sargassum tortile. Chem. Lett. 1985. [CrossRef]

55. Vera, J.; Castro, J.; Gonzalez, A.; Moenne, A. Seaweed Polysaccharides and Derived Oligosaccharides Stimulate Defense Responses and Protection against Pathogens in Plants. Mar. Drugs 2011, 44, 2514-2525. [CrossRef] [PubMed]

56. Jiménez, E.; Dorta, F.; Medina, C.; Ramírez, A.; Ramírez, I.; Peña-Cortés, H. Anti-Phytopathogenic Activities of Macro-Algae Extracts. Mar. Drugs 2011, 9, 739-756. [CrossRef]

57. Klarzynski, O.; Descamps, V.; Plesse, B.; Yvin, J.C.; Kloareg, B.; Fritig, B. Sulfated Fucan Oligosaccharides Elicit Defense Responses in Tobacco and Local and Systemic Resistance against Tobacco Mosaic Virus. Mol. Plant -Microbe Interact. 2003. [CrossRef] [PubMed]

58. Wilson, S. Frost Management in Cool Climate Vineyards; Final report to Wine Australia project number: UT 99/1; University of Tasmania: Hobart, Australia, 2001.

59. Patel, K.; Agarwal, P.; Agarwal, P.K. Kappaphycus alvarezii Sap Mitigates Abiotic-Induced Stress in Triticum durum by Modulating Metabolic Coordination and Improves Growth and Yield. J. Appl. Phycol. 2018. [CrossRef]

60. Dalal, A.; Bourstein, R.; Haish, N.; Shenhar, I.; Wallach, R.; Moshelion, M. Dynamic Physiological Phenotyping of DroughtStressed Pepper Plants Treated with "Productivity-Enhancing" and "Survivability-Enhancing" Biostimulants. Front. Plant Sci. 2019. [CrossRef] [PubMed]

61. Ganesan, S.; Vadivel, K.; Jayaraman, J. Sustainable Crop Disease Management Using Natural Products; CABI: Wallingford, UK, 2015. [CrossRef]

62. Ali, O.; Ramsubhag, A.; Jayaraman, J. Ascophyllum nodosum ( Linnaeus ) Le Jolis Seaweed Extract Improves Seed Germination in Tomato and Sweet Pepper under NaCl-Induced Salt Stress. Trop. Agric. 2018, 95, 141-148.

63. Vinoth, S.; Sundari; Gurusaravanan, P.; Sivakumar, S.; Siva, G.; Kumar, G.P.; Manju; Velmurugan, K.; Lakshminarayana, V.; Jayabalan, N. Evaluation of Seagrass Liquid Extract on Salt Stress Alleviation in Tomato Plants. Asian J. Plant Sci. 2017. [CrossRef] 
64. Murtic, S.; Oljaca, R.; Smajic Murtic, M.; Vranac, A.; Akagic, A.; Civic, H. Cherry Tomato Productivity as Influenced by Liquid Organic Fertilizer under Different Growth Conditions. J. Cent. Eur. Agric. 2018. [CrossRef]

65. Esserti, S.; Smaili, A.; Rifai, L.A.; Koussa, T.; Makroum, K.; Belfaiza, M.; Kabil, E.M.; Faize, L.; Burgos, L.; Alburquerque, N.; et al. Protective Effect of Three Brown Seaweed Extracts against Fungal and Bacterial Diseases of Tomato. J. Appl. Phycol. 2017. [CrossRef]

66. Demir, N.; Dural, B.; Yildirim, K. Effect of Seaweed Suspensions on Seed Germination of Tomato, Pepper and Aubergine. J. Biol. Sci. 2006, 1130-1133. [CrossRef]

67. Paradiković, N.; Vinković, T.; Vinković Vrček, I.; Žuntar, I.; Bojić, M.; Medić-Šarić, M. Effect of Natural Biostimulants on Yield and Nutritional Quality: An Example of Sweet Yellow Pepper (Capsicum annuum L.) Plants. J. Sci. Food Agric. 2011. [CrossRef]

68. Di Mola, I.; Cozzolino, E.; Ottaiano, L.; Giordano, M.; Rouphael, Y.; Colla, G.; Mori, M. Effect of Vegetal- And Seaweed ExtractBased Biostimulants on Agronomical and Leaf Quality Traits of Plastic Tunnel-Grown Baby Lettuce under Four Regimes of Nitrogen Fertilization. Agronomy 2019, 9, 571. [CrossRef]

69. Abetz, P.; Young, C.L. The Effect of Seaweed Extract Sprays Derived from Ascophyllum nodosum on Lettuce and Cauliflower Crops. Bot. Mar. 1983. [CrossRef]

70. Shukla, P.S.; Shotton, K.; Norman, E.; Neily, W.; Critchley, A.T.; Prithiviraj, B. Seaweed Extract Improve Drought Tolerance of Soybean by Regulating Stress-Response Genes. AoB Plants 2018. [CrossRef] [PubMed]

71. Martynenko, A.; Shotton, K.; Astatkie, T.; Petrash, G.; Fowler, C.; Neily, W.; Critchley, A.T. Thermal Imaging of Soybean Response to Drought Stress: The Effect of Ascophyllum nodosum Seaweed Extract. Springerplus 2016. [CrossRef] [PubMed]

72. Meszka, B.; Bielenin, A. Bioproducts in Control of Strawberry verticillium wilt. Phytopathologia 2008, $52,21-27$.

73. Washington, W.S.; Engleitner, S.; Boontjes, G.; Shanmuganathan, N. Effect of Fungicides, Seaweed Extracts, Tea Tree Oil, and Fungal Agents on Fruit Rot and Yield in Strawberry. Aust. J. Exp. Agric. 1999. [CrossRef]

74. El-Miniawy, S.M.; Ragab, M.E.; Youssef, S.M.; Metwally, A.A. Influence of Foliar Spraying of Seaweed Extract on Growth, Yield and Quality of Strawberry. J. App. Sci. Res. 2014, 10, 88-94.

75. Mattner, S.W.; Milinkovic, M.; Arioli, T. Increased Growth Response of Strawberry Roots to a Commercial Extract from Durvillaea potatorum and Ascophyllum nodosum. J. Appl. Phycol. 2018. [CrossRef]

76. Jayaraman, J.; Norrie, J.; Punja, Z.K. Commercial Extract from the Brown Seaweed Ascophyllum nodosum Reduces Fungal Diseases in Greenhouse Cucumber. J. Appl. Phycol. 2011, 15, 145-155. [CrossRef]

77. Jaulneau, V.; Lafitte, C.; Corio-Costet, M.F.; Stadnik, M.J.; Salamagne, S.; Briand, X.; Esquerré-Tugayé, M.T.; Dumas, B. An Ulva Armoricana Extract Protects Plants against Three Powdery Mildew Pathogens. Eur. J. Plant Pathol. 2011, 131, 393-401. [CrossRef]

78. Hidangmayum, A.; Sharma, R. Effect of Different Concentration of Commercial Seaweed Liquid Extract of Ascophylum nodosum on Germination of Onion (Allium cepa L.). Int. J. Sci. Res. 2017. [CrossRef]

79. Hidangmayum, A.; Sharma, R. Effect of Different Concentrations of Commercial Seaweed Liquid Extract of Ascophyllum nodosum as a Plant Bio Stimulant on Growth, Yield and Biochemical Constituents of Onion (Allium cepa L.). J. Pharmacogn. Phytochem. 2017, 6, 658-663.

80. Abbas, M.; Anwar, J.; Zafar-Ul-Hye, M.; Khan, R.I.; Saleem, M.; Rahi, A.A.; Danish, S.; Datta, R. Effect of Seaweed Extract on Productivity and Quality Attributes of Four Onion Cultivars. Horticulturae 2020, 6, 28. [CrossRef]

81. Almaroai, Y.A.; Eissa, M.A. Role of Marine Algae Extracts in Water Stress Resistance of Onion Under Semiarid Conditions. J. Soil Sci. Plant Nutr. 2020. [CrossRef]

82. Haider, M.W.; Ayyub, C.M.; Pervez, M.A.; Asad, H.U.; Manan, A.; Raza, S.A.; Ashraf, I. Impact of Foliar Application of Seaweed Extract on Growth, Yield and Quality of Potato (Solanum tuberosum L.). Soil Environ. 2012, 31, 157-162.

83. Blunden, G.; Wildgoose, P.B. The Effects of Aqueous Seaweed Extract and Kinetin on Potato Yields. J. Sci. Food Agric. 1977. [CrossRef]

84. Dwelle, R.B.; Hurley, P.J. The Effects of Foliar Application of Cytokinins on Potato Yields in Southeastern Idaho. Am. Potato J. 1984. [CrossRef]

85. Prajapati, A.; Patel, C.K.; Singh, N.; Jain, S.K.; Chongtham, S.K.; Maheshwari, M.N.; Patel, C.R.; Pate, R.N. Evaluation of Seaweed Extract on Growth and Yield of Potato. Environ. Ecol. 2016, 34, 605-608.

86. Dziugiel, T.; Wadas, W. Possibility of Increasing Early Crop Potato Yield with Foliar Application of Seaweed Extracts and Humic Acids. J. Cent. Eur. Agric. 2020. [CrossRef]

87. Mattner, S.W.; Wite, D.; Riches, D.A.; Porter, I.J.; Arioli, T. The Effect of Kelp Extract on Seedling Establishment of Broccoli on Contrasting Soil Types in Southern Victoria, Australia. Biol. Agric. Hortic. 2013. [CrossRef]

88. Gajc-Wolska, J.; Spiewski, T.; Grabowska, A. The Effect of Seaweed Extracts on the Yield and Quality Parameters of Broccoli (Brassica oleracea var. cymosa L.) in Open Field Production. Acta Hortic. 2012. [CrossRef]

89. Rouphael, Y.; Giordano, M.; Cardarelli, M.; Cozzolino, E.; Mori, M.; Kyriacou, M.C.; Bonini, P.; Colla, G. Plant-and Seaweed-Based Extracts Increase Yield but Differentially Modulate Nutritional Quality of Greenhouse Spinach through Biostimulant Action. Agronomy 2018, 8, 126. [CrossRef]

90. Zahid, P.B. Preparation of Organic Fertilizer from Seaweed and Its Effect on the Growth of Some Vegetable and Ornamental Plants. Pakistan J. Biol. Sci. 1999. [CrossRef]

91. Poberezny, J.; Szczepanek, M.; Wszelaczynska, E.; Prus, P. The Quality of Carrot after Field Biostimulant Application and after Storage. Sustainability 2020, 12, 1386. [CrossRef] 
92. Kiraci, S. Effects of Seaweed and Different Farm Manures on Growth and Yield of Organic Carrots. J. Plant Nutr. 2018. [CrossRef]

93. Alam, M.Z.; Braun, G.; Norrie, J.; Hodges, D.M. Ascophyllum Extract Application Can Promote Plant Growth and Root Yield in Carrot Associated with Increased Root-Zone Soil Microbial Activity. Can. J. Plant Sci. 2014. [CrossRef]

94. Jayaraj, J.; Wan, A.; Rahman, M.; Punja, Z.K. Seaweed Extract Reduces Foliar Fungal Diseases on Carrot. Crop Prot. 2008, 44, 345-366. [CrossRef]

95. Eggen, T.; Asp, T.N.; Grave, K.; Hormazabal, V. Uptake and Translocation of Metformin, Ciprofloxacin and Narasin in Forageand Crop Plants. Chemosphere 2011. [CrossRef] [PubMed]

96. Kasim, W.A.; Hamada, E.A.M.; Shams El-Din, N.G.; Eskander, S.K. Influence of Seaweed Extracts on the Growth, Some Metabolic Activities and Yield of Wheat Grown under Drought Stress. Int. J. Agron. Agric. Res. 2015, 7, 173-189.

97. Sharma, S.; Chen, C.; Khatri, K.; Rathore, M.S.; Pandey, S.P. Gracilaria Dura Extract Confers Drought Tolerance in Wheat by Modulating Abscisic Acid Homeostasis. Plant Physiol. Biochem. 2019. [CrossRef] [PubMed]

98. Shah, M.T.; Zodape, S.T.; Chaudhary, D.R.; Eswaran, K.; Chikara, J. Seaweed Sap As An Alternative Liquid Fertilizer For Yield And Quality Improvement Of Wheat. J. Plant Nutr. 2013. [CrossRef]

99. Salim, B.B.M. Influence of Biochar and Seaweed Extract Applications on Growth, Yield and Mineral Composition of Wheat (Triticum aestivum L.) under Sandy Soil Conditions. Ann. Agric. Sci. 2016. [CrossRef]

100. Amaral Carvalho, M.E.; de Camargo e Castro, P.R.; Gallo, L.A.; de Castro Ferraz Junior, M.V. Seaweed Extract Provides Development and Production of Wheat. Rev. Agrar. 2014, 7, 166-170.

101. Carolina Feitosa de Vasconcelos, A. Amelioration of Drought Stress on Plants under Biostimulant Sources. Plant Stress Physiol. 2020. [CrossRef]

102. Begum, M.; Bordoloi, B.C.; Singha, D.D.; Ojha, N.J. Role of Seaweed Extract on Growth, Yield and Quality of Some Agricultural Crops: A Review. Agric. Rev. 2018. [CrossRef]

103. Pramanick, B.; Brahmachari, K.; Ghosh, A.; Zodape, S.T. Effect of Seaweed Saps on Growth and Yield Improvement of Transplanted Rice in Old Alluvial Soil of West Bengal. Bangladesh J. Bot. 2014. [CrossRef]

104. Effect of Seaweed Extracts on Growth and Yield of Rice Plants. Nusant. Biosci. 2010. [CrossRef]

105. Layek, J.; Das, A.; Idapuganti, R.G.; Sarkar, D.; Ghosh, A.; Zodape, S.T.; Lal, R.; Yadav, G.S.; Panwar, A.S.; Ngachan, S.; et al. Seaweed Extract as Organic Bio-Stimulant Improves Productivity and Quality of Rice in Eastern Himalayas. J. Appl. Phycol. 2018. [CrossRef]

106. Spinelli, F.; Fiori, G.; Noferini, M.; Sprocatti, M.; Costa, G. Perspectives on the Use of a Seaweed Extract to Moderate the Negative Effects of Alternate Bearing in Apple Trees. J. Hortic. Sci. Biotechnol. 2009, 84, 131-137. [CrossRef]

107. Malaguti, D.; Rombolà, A.D.; Gerin, M.; Simoni, G.; Tagliavini, M.; Marangoni, B. Effect of Seaweed Extracts-Based Leaf Sprays on the Mineral Status, Yield and Fruit Quality of Apple. Acta Hortic. 2002. [CrossRef]

108. de Sousa, A.M.; Ayub, R.A.; Viencz, T.; Botelho, R.V. Fruit Set and Yield of Apple Trees Cv. Gala Treated with Seaweed Extract of Ascophyllum nodosum and Thidiazuron. Rev. Bras. Frutic. 2019. [CrossRef]

109. Soppelsa, S.; Kelderer, M.; Casera, C.; Bassi, M.; Robatscher, P.; Andreotti, C. Use of Biostimulants for Organic Apple Production: Effects on Tree Growth, Yield, and Fruit Quality at Harvest and during Storage. Front. Plant Sci. 2018. [CrossRef] [PubMed]

110. Jeannin, I.; Lescure, J.C.; Morot-Gaudry, J.F. The Effects of Aqueous Seaweed Sprays on the Growth of Maize. Bot. Mar. 1991. [CrossRef]

111. Basavaraja, P.K.; Yogendra, N.D.; Zodape, S.T.; Prakash, R.; Ghosh, A. Effect of Seaweed Sap as Foliar Spray on Growth and Yield of Hybrid Maize. J. Plant Nutr. 2018. [CrossRef]

112. Pal, A.; Dwivedi, S.K.; Maurya, P.K.; Kanwar, P. Effect of Seaweed Saps on Growth, Yield, Nutrient Uptake and Economic Improvement of Maize (Sweet Corn). J. Appl. Nat. Sci. 2015. [CrossRef]

113. Layek, J.; Das, A.; Ramkrushna, G.I.; Ghosh, A.; Panwar, A.S.; Krishnappa, R.; Ngachan, S.V. Effect of Seaweed Sap on Germination, Growth and Productivity of Maize (Zea mays) in North Eastern Himalayas. Indian J. Agron. 2016, 61, 354-359.

114. Devi, R.; Singh, S.; Singh, M.K.; Pal, S.K.; Perween, S.; Kumari, J.; Zodape, S.T.; Ghosh, A. Seaweed Sap As Productivity Booster Of Maize. Bioscan 2015, 10, 1303-1305.

115. Al-Musawi, M.A.H.M. Effect of Foliar Application with Algae Extracts on Fruit Quality of Sour Orange, Citrus aurantium L. J. Environ. Sci. Pollut. Res. 2018. [CrossRef]

116. Fornes, F.; Sánchez-Perales, M.; Guardiola, J.L. Effect of a Seaweed Extract on the Productivity of "de Nules" Clementine Mandarin and Navelina Orange. Bot. Mar. 2002, 43, 345-354. [CrossRef]

117. Fornes, F.; Sánchez-Perales, M.; Guardiola, J.L. Effect of A Seaweed Extract on Citrus Fruit Maturation. Acta Hortic. 1995. [CrossRef]

118. Gomathi, R.; Kohila, S.; Ramachandiran, K. Evaluating the Effect of Seaweed Formulations on the Quality and Yield of Sugarcane. Madras Agric. J. 2017, 104, 1.

119. da Silveira, L.C.I.; Mattos, P.; Mógor, Á.F.; Daros, E.; de Oliveira Bettini, M.; Norrie, J. Effect of Kelp Extract on Sugarcane Plantlets Biomass Accumulation. Idesia (Arica) 2015. [CrossRef]

120. Grundy, J.; Stoker, C.; Carré, I.A. Circadian Regulation of Abiotic Stress Tolerance in Plants. Front. Plant Sci. 2015. [CrossRef] [PubMed] 
121. Billard, V.; Etienne, P.; Jannin, L.; Garnica, M.; Cruz, F.; Garcia-Mina, J.M.; Yvin, J.C.; Ourry, A. Two Biostimulants Derived from Algae or Humic Acid Induce Similar Responses in the Mineral Content and Gene Expression of Winter Oilseed Rape (Brassica napus L.). J. Plant Growth Regul. 2014. [CrossRef]

122. El Boukhari, M.E.M.; Barakate, M.; Bouhia, Y.; Lyamlouli, K. Trends in Seaweed Extract Based Biostimulants: Manufacturing Process and Beneficial Effect on Soil-Plant Systems. Plants 2020, 9, 359. [CrossRef]

123. Fan, D.; Hodges, D.M.; Critchley, A.T.; Prithiviraj, B. A Commercial Extract of Brown Macroalga (Ascophyllum nodosum ) Affects Yield and the Nutritional Quality of Spinach In Vitro. Commun. Soil Sci. Plant Anal. 2013. [CrossRef]

124. Jannin, L.; Arkoun, M.; Etienne, P.; Laîné, P.; Goux, D.; Garnica, M.; Fuentes, M.; Francisco, S.S.; Baigorri, R.; Cruz, F.; et al. Brassica Napus Growth Is Promoted by Ascophyllum nodosum (L.) Le Jol. Seaweed Extract: Microarray Analysis and Physiological Characterization of N, C, and S Metabolisms. J. Plant Growth Regul. 2013. [CrossRef]

125. Nair, P.; Kandasamy, S.; Zhang, J.; Ji, X.; Kirby, C.; Benkel, B.; Hodges, M.D.; Critchley, A.T.; Hiltz, D.; Prithiviraj, B. Transcriptional and Metabolomic Analysis of Ascophyllum nodosum Mediated Freezing Tolerance in Arabidopsis thaliana. BMC Genom. 2012, 13, 1-23. [CrossRef] [PubMed]

126. Zamani-Babgohari, M.; Critchley, A.T.; Norrie, J.; Prithiviraj, B. Increased Freezing Stress Tolerance of Nicotiana Tabacum L. Cv. Bright Yellow-2 Cell Cultures with the Medium Addition of Ascophyllum nodosum (L.) Le Jolis Extract. Vitr. Cell. Dev. Biol. Plant 2019. [CrossRef]

127. Santaniello, A.; Scartazza, A.; Gresta, F.; Loreti, E.; Biasone, A.; Di Tommaso, D.; Piaggesi, A.; Perata, P. Ascophyllum nodosum Seaweed Extract Alleviates Drought Stress in Arabidopsis by Affecting Photosynthetic Performance and Related Gene Expression. Front. Plant Sci. 2017. [CrossRef]

128. Goñi, O.; Quille, P.; O'Connell, S. Ascophyllum nodosum Extract Biostimulants and Their Role in Enhancing Tolerance to Drought Stress in Tomato Plants. Plant Physiol. Biochem. 2018. [CrossRef] [PubMed]

129. Xu, Y.; Zheng, X.; Song, Y.; Zhu, L.; Yu, Z.; Gan, L.; Zhou, S.; Liu, H.; Wen, F.; Zhu, C. NtLTP4, a Lipid Transfer Protein That Enhances Salt and Drought Stresses Tolerance in Nicotiana tabacum. Sci. Rep. 2018. [CrossRef] [PubMed]

130. Jithesh, M.N.; Shukla, P.S.; Kant, P.; Joshi, J.; Critchley, A.T.; Prithiviraj, B. Physiological and Transcriptomics Analyses Reveal That Ascophyllum nodosum Extracts Induce Salinity Tolerance in Arabidopsis by Regulating the Expression of Stress Responsive Genes. J. Plant Growth Regul. 2019. [CrossRef]

131. Elansary, H.O.; Yessoufou, K.; Abdel-Hamid, A.M.E.; El-Esawi, M.A.; Ali, H.; Elshikh, M.S. Seaweed Extracts Enhance Salam Turfgrass Performance during Prolonged Irrigation Intervals and Saline Shock. Front. Plant Sci. 2017. [CrossRef]

132. Cluzet, S.; Torregrosa, C.; Jacquet, C.; Lafitte, C.; Fournier, J.; Mercier, L.; Salamagne, S.; Briand, X.; Esquerré-Tugayé, M.T.; Dumas, B. Gene Expression Profiling and Protection of Medicago truncatula against a Fungal Infection in Response to an Elicitor from Green Algae Ulva Spp. Plant Cell Environ. 2004. [CrossRef]

133. Kunkel, B.N.; Brooks, D.M. Cross Talk between Signaling Pathways in Pathogen Defense. Curr. Opin. Plant Biol. 2002, 34, 354-366. [CrossRef]

134. Mabeau, S.; Kloareg, B. Isolation and Analysis of the Cell Walls of Brown Algae: Fucus Spiralis, F. ceranoides, F. vesiculosus, F. serratus, Bifurcaria bifurcata and Laminaria digitata. J. Exp. Bot. 1987. [CrossRef]

135. Chevolot, L.; Mulloy, B.; Ratiskol, J.; Foucault, A.; Colliec-Jouault, S. A Disaccharide Repeat Unit Is the Major Structure in Fucoidans from Two Species of Brown Algae. Carbohydr. Res. 2001. [CrossRef]

136. Klarzynski, O.; Plesse, B.; Joubert, J.M.; Yvin, J.C.; Kopp, M.; Kloareg, B.; Fritig, B. Linear SS-1,3-Glucans Are Elicitors of Defense Responses in Tobacco. Plant Physiol. 2000, 45, 567-588. [CrossRef]

137. Mercier, L.; Lafitte, C.; Borderies, G.; Briand, X.; Esquerré-Tugayé, M.T.; Fournier, J. The Algal Polysaccharide Carrageenans Can Act as an Elicitor of Plant Defence. New Phytol. 2001, 6, 66-87. [CrossRef]

138. El Modafar, C.; Elgadda, M.; El Boutachfaiti, R.; Abouraicha, E.; Zehhar, N.; Petit, E.; El Alaoui-Talibi, Z.; Courtois, B.; Courtois, J. Induction of Natural Defence Accompanied by Salicylic Acid-Dependant Systemic Acquired Resistance in Tomato Seedlings in Response to Bioelicitors Isolated from Green Algae. Sci. Hortic. (Amsterdam) 2012, 138, 55-63. [CrossRef]

139. Sahayaraj, K.; Kalidas, S. Evaluation of Nymphicidal and Ovicidal Effect of a Seaweed, Padina pavonica (Linn.) (Phaeophyceae) on Cotton Pest, Dysdercus cingulatus (Fab.). Indian J. Mar. Sci. 2011, 40, 125-129.

140. El-Ansary, M.S.M.; Hamouda, R.A. Biocontrol of Root-Knot Nematode Infected Banana Plants by Some Marine Algae. Russ. J. Mar. Biol. 2014. [CrossRef]

141. Dubiella, U.; Seybold, H.; Durian, G.; Komander, E.; Lassig, R.; Witte, C.-P.; Schulze, W.X.; Romeis, T. Calcium-Dependent Protein Kinase/NADPH Oxidase Activation Circuit Is Required for Rapid Defense Signal Propagation. Proc. Natl. Acad. Sci. USA 2013, 110, 8744-8749. [CrossRef] [PubMed]

142. Delaunois, B.; Farace, G.; Jeandet, P.; Clément, C.; Baillieul, F.; Dorey, S.; Cordelier, S. Elicitors as Alternative Strategy to Pesticides in Grapevine? Current Knowledge on Their Mode of Action from Controlled Conditions to Vineyard. Environ. Sci. Pollut. Res. 2014, 43, 111-166. [CrossRef] [PubMed]

143. Nihorimbere, V.; Ongena, M.; Smargiassi, M.; Thonart, P. Beneficial Effect of the Rhizosphere Microbial Community for Plant Growth and Health. Benef. Eff. Rhizosph. Microb. Community Plant Growth Health 2011, 15, 327-337.

144. Renaut, S.; Masse, J.; Norrie, J.P.; Blal, B.; Hijri, M. A Commercial Seaweed Extract Structured Microbial Communities Associated with Tomato and Pepper Roots and Significantly Increased Crop Yield. Microb. Biotechnol. 2019. [CrossRef] [PubMed] 
145. Wang, Y.; Fu, F.; Li, J.; Wang, G.; Wu, M.; Zhan, J.; Chen, X.; Mao, Z. Effects of Seaweed Fertilizer on the Growth of Malus hupehensis Rehd. Seedlings, Soil Enzyme Activities and Fungal Communities under Replant Condition. Eur. J. Soil Biol. 2016. [CrossRef]

146. Yalçın, S.; Şükran Okudan, E.; Karakaş, Ö.; Önem, A.N.; Sözgen Başkan, K. Identification and Quantification of Some Phytohormones in Seaweeds Using UPLC-MS/MS. J. Liq. Chromatogr. Relat. Technol. 2019. [CrossRef]

147. Stirk, W.A.; Van Staden, J. Plant Growth Regulators in Seaweeds: Occurrence, Regulation and Functions; Elsevier: Amsterdam, The Netherlands, 2014; Volume 71.

148. MacKinnon, S.L.; Hiltz, D.; Ugarte, R.; Craft, C.A. Improved Methods of Analysis for Betaines in Ascophyllum nodosum and Its Commercial Seaweed Extracts. J. Appl. Phycol. 2010, 22, 489-494. [CrossRef]

149. McNeil, S.D.; Nuccio, M.L.; Hanson, A.D. Betaines and Related Osmoprotectants. Targets for Metabolic Engineering of Stress Resistance. Plant Physiol. 1999, 67, 45-56. [CrossRef] [PubMed]

150. Nabil, S.; Cosson, J. Seasonal Variations in Sterol Composition of Delesseria sanguinea (Ceramiales, Rhodophyta). Hydrobiologia 1996. [CrossRef]

151. Hamdy, A.E.A.; Dawes, C.J. Proximate Constituents and Lipid Chemistry in Two Species of Sargassum from the West Coast of Florida. Bot. Mar. 1988. [CrossRef]

152. Govindan, M.; Hodge, J.D.; Brown, K.A.; Nuñez-Smith, M. Distribution of Cholesterol in Caribbean Marine Algae. Steroids 1993. [CrossRef]

153. Kumari, P.; Kumar, M.; Reddy, C.R.K.; Jha, B. Algal Lipids, Fatty Acids and Sterols. In Functional Ingredients from Algae for Foods and Nutraceuticals; Elsevier: Amsterdam, The Netherlands, 2013.

154. Poojary, M.M.; Barba, F.J.; Aliakbarian, B.; Donsì, F.; Pataro, G.; Dias, D.A.; Juliano, P. Innovative Alternative Technologies to Extract Carotenoids from Microalgae and Seaweeds. Mar. Drugs 2016, 14, 214. [CrossRef]

155. Othman, R.; Amin, N.A.; Sani, M.S.A.; Fadzillah, N.A.; Jamaludin, M.A. Carotenoid and Chlorophyll Profiles in Five Species of Malaysian Seaweed as Potential Halal Active Pharmaceutical Ingredient (API). Int. J. Adv. Sci. Eng. Inf. Technol. 2018. [CrossRef]

156. Circuncisão, A.R.; Catarino, M.D.; Cardoso, S.M.; Silva, A.M.S. Minerals from Macroalgae Origin: Health Benefits and Risks for Consumers. Mar. Drugs 2018, 16, 400. [CrossRef]

157. Seaweeds, O.F. Mineral Nutrients Found in Seaweed and Their Function. Available online: http:/ /www.ocean-fresh-seaweeds. com/seaweed_mineral_nutrients_and_function.html (accessed on 18 September 2020).

158. Parthiban, C.; Saranya, C.; Girija, K.; Hemalatha, A.; Suresh, M.; Anantharaman, P. Biochemical Composition of Some Selected Seaweeds from Tuticorin Coast. Pelagia Res. Libr. 2013, 4, 362-366.

159. Cotas, J.; Leandro, A.; Monteiro, P.; Pacheco, D.; Figueirinha, A.; Goncalves, A.M.M.; Da Silva, G.J.; Pereira, L. Seaweed Phenolics: From Extraction to Applications. Mar. Drugs 2020, 18, 384. [CrossRef]

160. Chojnacka, K.; Kim, S.K. Introduction of Marine Algae Extracts. Mar. Algae Extr. Process. Prod. Appl. 2015. [CrossRef]

161. El-Baroty, G.S.; El-Baz, F.K.; Abd-Elmoein, A.; Abd El Baky, H.H.; Ali, M.M.; Ibrahim, A.E. Evaluation of Glycolipids of Some Egyptian Marine Algae as a Source of Bioactive Substances. Electron. J. Environ. Agric. Food Chem. 2011, 10, $2114-2128$.

162. Guschina, I.A.; Harwood, J.L. Lipids and Lipid Metabolism in Eukaryotic Algae. Prog. Lipid Res. 2006. [CrossRef] [PubMed]

163. Barbosa, M.; Valentão, P.; Andrade, P.B. Biologically Active Oxylipins from Enzymatic and Nonenzymatic Routes in Macroalgae. Mar. Drugs 2016, 14, 23. [CrossRef]

164. Pangestuti, R.; Kim, S.K. Seaweed Proteins, Peptides, and Amino Acids. Seaweed Sustain. Food Non-Food Appl. 2015. [CrossRef]

165. Fleurence, J.; Morançais, M.; Dumay, J. Seaweed Proteins. In Proteins in Food Processing, 2nd ed.; Elsevier: Amsterdam, The Netherlands, 2018.

166. Yu, K.X.; Jantan, I.; Ahmad, R.; Wong, C.L. The Major Bioactive Components of Seaweeds and Their Mosquitocidal Potential. Parasitol. Res. 2014. [CrossRef] [PubMed]

167. Dubey, N.K. Natural Products in Plant Pest Management; CABI: Wallingford, UK, 2010.

168. Ratnadass, A.; Fernandes, P.; Avelino, J.; Habib, R. Plant Species Diversity for Sustainable Management of Crop Pests and Diseases in Agroecosystems: A Review. Agron. Sustain. Dev. 2012. [CrossRef]

169. Thundiyil, J.G.; Stober, J.; Besbelli, N.; Pronczuk, J. Acute Pesticide Poisoning: A Proposed Classification Tool. Bull. World Health Organ. 2008. [CrossRef]

170. Omura, M.; Hirata, M.; Zhao, M.; Tanaka, A.; Inoue, N. Comparative Testicular Toxicities of Two Isomers of Dichloropropanol, 2,3-Dichloro-1-Propanol, and 1,3-Dichloro-2-Propanol, and Their Metabolites Alpha-Chlorohydrin and Epichlorohydrin, and the Potent Testicular Toxicant 1,2-Dibromo-3-Chloropropane. Bull. Environ. Contam. Toxicol. 1995. [CrossRef]

171. Feng, W.; Zheng, X. Essential Oils to Control Alternaria Alternata in Vitro and in Vivo. Food Control 2007. [CrossRef]

172. Caradonia, F.; Battaglia, V.; Righi, L.; Pascali, G.; La Torre, A. Plant Biostimulant Regulatory Framework: Prospects in Europe and Current Situation at International Level. J. Plant Growth Regul. 2019. [CrossRef]

173. Singh, A.K. Integrated Crop, Nutrient and Pest Management for Improving Tomato, Brinjal and Chilli Productivity in Acid Soils. Int. J. Plant Prot. 2017. [CrossRef]

174. Chinnadurai, C.; Ramkissoon, A.; Rajendran, R.; deAspa, S.; Ramsubhag, A.; Jayaraj, J. Integrated Disease Management in Pumpkin in the Southern Caribbean. Trop. Agric. Univ. West Indies 2018, 95, 132-140.

175. Zodape, S.T. Seaweeds As a Biofertilizer. J. Sci. Ind. Res. (India) 2001, 60, 378-382. 
176. Tejada-Tejada, P.; Rodriguez-Rodriguez, Y.; Rodriguez, L.E.; Perdomo, O.P.; Boluda, C.J. Quantification of Hevy Metals in Sargassum natans and Sargassum fluitans Arrived to the Coasts of Dominican Republic during 2019. In Proceedings of the Caribbean Science and Innovation Meeting, Pointe-à-Pitre, France, 19-22 October 2019.

177. Godlewska, K.; Michalak, I.; Tuhy, L.; Chojnacka, K. Plant Growth Biostimulants Based on Different Methods of Seaweed Extraction with Water. Biomed Res. Int. 2016. [CrossRef]

178. El-Naggar, N.E.A.; Rabei, N.H. Bioprocessing Optimization for Efficient Simultaneous Removal of Methylene Blue and Nickel by Gracilaria Seaweed Biomass. Sci. Rep. 2020. [CrossRef] [PubMed]

179. Susilorini, R.M.I.R.; Hardjasaputra, H.; Sri, T.; Galih, H.; RPeksa, W.S.; Ginanjar, H.; Joko, S. The Advantage of Natural Polymer Modified Mortar with Seaweed: Green Construction Material Innovation for Sustainable Concrete. Procedia Eng. 2014. [CrossRef]

180. van Tussenbroek, B.I.; Hernández Arana, H.A.; Rodríguez-Martínez, R.E.; Espinoza-Avalos, J.; Canizales-Flores, H.M.; GonzálezGodoy, C.E.; Barba-Santos, M.G.; Vega-Zepeda, A.; Collado-Vides, L. Severe Impacts of Brown Tides Caused by Sargassum spp. on near-Shore Caribbean Seagrass Communities. Mar. Pollut. Bull. 2017. [CrossRef] 